\title{
Archaeological Survey at Rancho de las Cabras, San Antonio Missions National Historic Park, 41WN30, Wilson County, Texas
}

\author{
Diane A. Cargill \\ Center for Archaeological Research \\ Maureen Brown \\ Center for Archaeological Research \\ Lee C. Nordt \\ Center for Archaeological Research \\ C. Britt Bousman \\ Department of Anthropology, Texas State University
}

Follow this and additional works at: https://scholarworks.sfasu.edu/ita

Part of the American Material Culture Commons, Archaeological Anthropology Commons, Environmental Studies Commons, Other American Studies Commons, Other Arts and Humanities Commons, Other History of Art, Architecture, and Archaeology Commons, and the United States History Commons

Tell us how this article helped you.

This Article is brought to you for free and open access by the Center for Regional Heritage Research at SFA ScholarWorks. It has been accepted for inclusion in Index of Texas Archaeology: Open Access Gray Literature from the Lone Star State by an authorized editor of SFA ScholarWorks. For more information, please contact cdsscholarworks@sfasu.edu. 


\section{Archaeological Survey at Rancho de las Cabras, San Antonio Missions National Historic Park, 41WN30, Wilson County, Texas \\ Creative Commons License \\ (c) (1) (8)}

This work is licensed under a Creative Commons Attribution-NonCommercial 4.0 International License 


\title{
Archaeological Survey at Rancho de las Cabras, San Antonio Missions National Historical Park, 41WN30, Wilson County, Texas
}

\author{
Diane A. Cargill, Maureen Brown, Lee C. Nordt, \\ and C. Britt Bousman
}

San Antonio Missions National Historical Park

Contract Numbers 1443PX7600-97030 and 1443PX7600-97041

Texas Antiquities Committee Permit No. 1849

(C)copyright 1998

Center for Archaeological Research

The University of Texas at San Antonio

Archaeological Survey Report, No. 286 
The following information is provided in accordance with the General Rules of Practice and Procedure, Chapter 41.11 (Investigative Reports), Texas Antiquities Committee:

1. Type of investigation: Survey

2. Project name: Rancho de las Cabras Southern Tract and Access Road

3. County: Wilson

4. Principal investigators: Robert J. Hard and C. Britt Bousmann

5. Name and location of sponsoring agency: National Park Service, San Antonio Missions National Historical Park, San Antonio, Texas

6. Texas Antiquities Permit No.: 1849

7. Published by the Center for Archaeological Research, The University of Texas at San Antonio, 6900 N. Loop 1604 W., San Antonio, Texas 78249-0658, 1998

A list of publications offered by the Center for Archaeological Research is available. Call (210) 458-4378; write to the Center for Archaeological Research, The University of Texas at San Antonio, 6900 N. Loop 1604 W., San Antonio, Texas 78249-0658; e-mail to car@lonestar.utsa.edu; or visit CAR's Web site at http://www.csbs.utsa.edu/ research/car/index.htm. 


\begin{abstract}
A two-stage archaeological investigation and preliminary geomorphological assessment was conducted at Rancho de las Cabras, San Antonio Missions National Historical Park, by the Center for Archaeological Research (CAR) of The University of Texas at San Antonio for the National Park Service (NPS). The investigation was prompted by NPS plans to construct a parking lot and visitors' center near the Spanish colonial ruins (41WN30). The geomorphological investigations are preliminary, with more fieldwork needed to test the proposed working model; however, the geomorphological conclusions suggest widespread potential for finding buried prehistoric sites in the alluvial terraces.

Four newly identified surface lithic scatter sites were recorded and mapped. Sites 41WN90, 41WN92, and 41WN93 are presently on NPS property and 41WN91 is located on private land. These sites are located in the upland Early to Middle Pleistocene Leona Formation. Due to the paucity of surface and subsurface cultural material, and to previous subsurface disturbance in the form of deep root cutting and plowing, the four sites are considered to have minimal research potential.

The three sites on NPS property are currently included in the National Register nomination filed in 1977; however, the systematic collection of surface artifacts conducted during the current investigation, has in effect, mitigated these sites by exhausting their research potential. Site $41 \mathrm{WN} 91$, located on private property, is not recommended as eligible for inclusion in the National Register. During the course of the archaeological investigation, two important cultural areas were identified near the Las Cabras ruins. Artifacts recovered near the western edge of the ruins demonstrate their association with the Colonial ranch; this area has been identified as culturally sensitive. West of the ruins, the second area is comprised of an isolated dark soil (over-thickened A-horizon) which may have formed from anthropogenic activities related to the Colonial ranch. Therefore, prior to any future ground disturbing activities, it is recommended that additional testing be conducted in the archaeologically sensitive area, the over-thickened A-horizon, and the alluvial terraces.
\end{abstract}




\section{Contents}

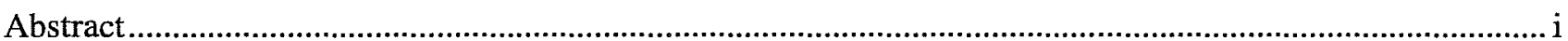

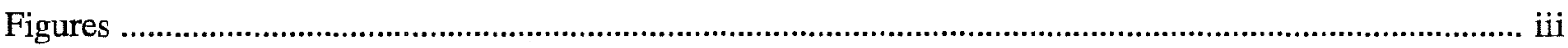

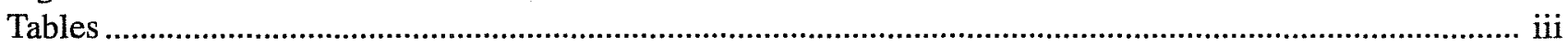

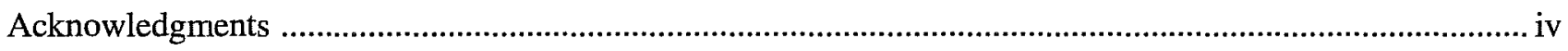

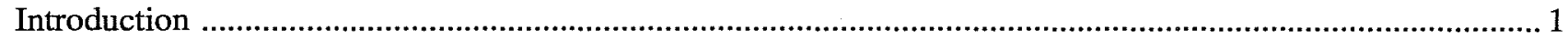

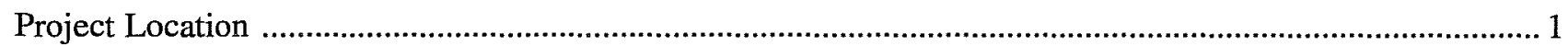

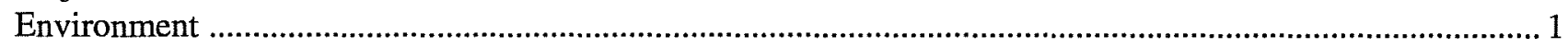

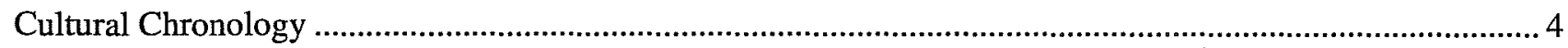

Previous Archaeological Investigations at Rancho de las Cabras ....................................................... 8

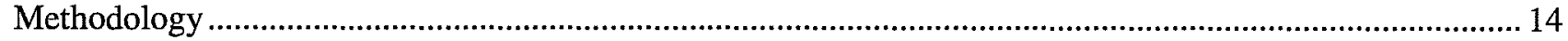

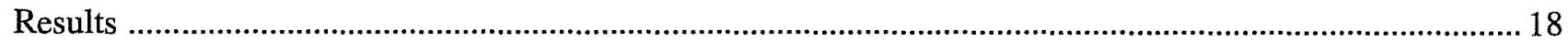

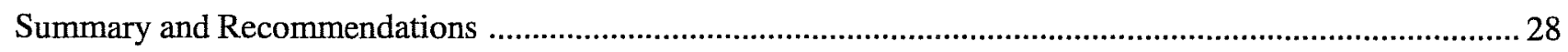

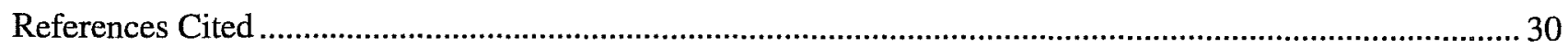

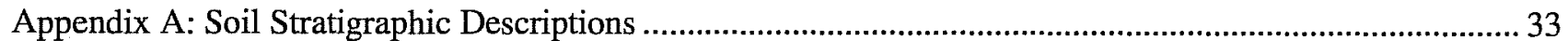




\section{Figures}

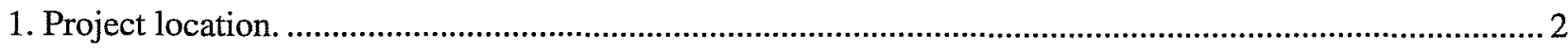

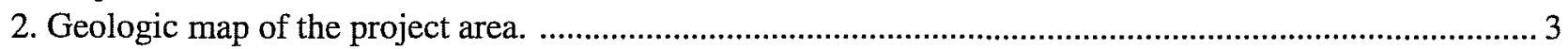

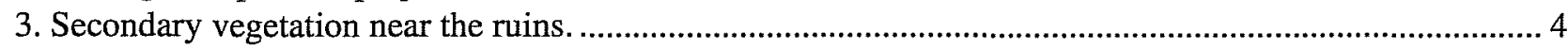

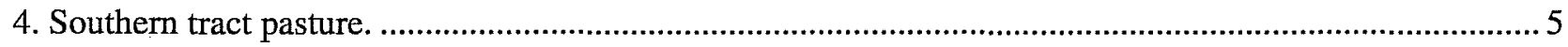

5. CAR's 1980-1984 archaeological investigations of Rancho de las Cabras. ......................................... 10

6. Landform map of the project area. ......................................................................................... 15

7. Stage 1 and 2 archaeological survey and testing, shovel test locations, $41 \mathrm{WN} 90$ and 41 WN91 site boundaries, characterization units, and concentration areas. .................................................... 16

8. Stage 2 access road, shovel test locations, and 41WN92 and 41WN93 site boundaries,

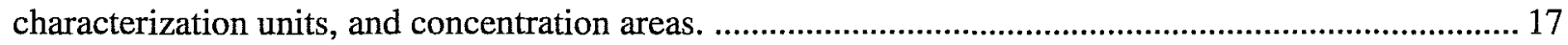

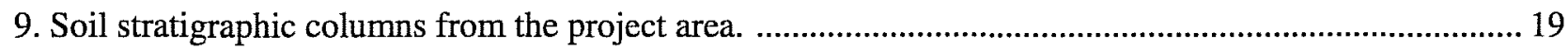

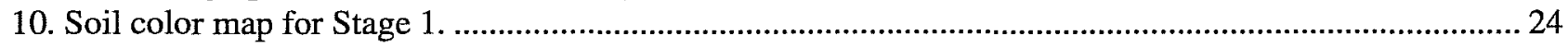

\section{Tables}

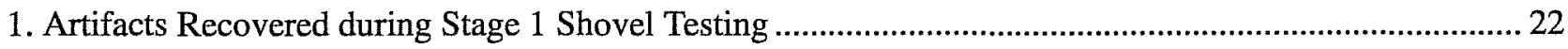

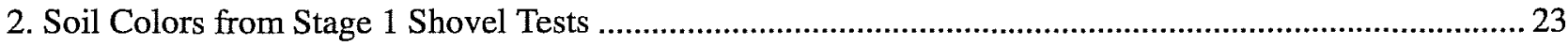

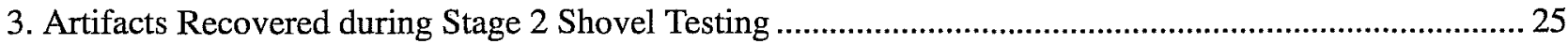

4. Artifacts Recovered from Characterization Units and Special Collections at 41WN90 .........................26

5. Total Characterization Area Collected and Artifact Density for 41WN90, 41WN91, and 41WN93 ........26

6. Artifacts Recovered from Characterization Units and Special Collections at 41WN91 ..........................2 27

7. Artifacts Recovered from Characterization Units and Special Collections at 41WN93 ..........................28 


\section{Acknowledgments}

Several people contributed in various ways to the completion of this project. Thanks go to Mark Chavez and James Oliver of the National Park Service for their assistance in both the office and in the field. A special acknowledgement is due Mr. Winston Southern who presently owns the southern tract property. He was especially kind and helpful, answering our many questions about the project area and allowing us full access to his property.

We would like to thank Robert J. Hard and C. Britt Bousman, director and associate director of CAR, for serving as principal investigators. Critical to any field investigation is a dedicated field crew; therefore, special thanks go to Jeff Durst, Chris Horrell, Kevin Hanselka, Richard Jones, Kim Kvernes, Tony Lyle, Wilson McKinney, Bruce Moses, Gloria Murguia, Owen Ford, and Toni Figueroa; and to student interns Ruth Mathews, Chris Cooley, and Eve Santos. Lee Nordt and Britt Bousman conducted the preliminary geomorphological assessment of the park and Barbara Meissner identified the faunal remains. Thanks to Bruce Moses, Chris Butler, and Barbara Meissner for drafting the maps in this report. Thanks to Anne Fox for her helpful suggestions following a draft reading of this report, and to Marcie Renner, our technical editor, for her ability to expertly manage and produce numerous reports simultaneously. 


\section{Introduction}

An archaeological survey at the site of Rancho de las Cabras was conducted in June and July, and September and October of 1997, by the Center for Archaeological Research (CAR) of The University of Texas at San Antonio for the National Park Service (NPS). In compliance with Section 106 of the National Historic Preservation Act and the Texas Antiquities Code, the work was performed under Texas Antiquities Permit No. 1849. The investigation was necessitated by NPS plans to build a parking lot and a visitors' center. The contractual agreement between NPS and CAR called for a two-stage investigation to document cultural resources in the project area.

The first stage consisted of a pedestrian survey and shovel testing of an area directly west and south of the ruins of Rancho de las Cabras (41WN30) (Figure 1). Included in the first stage was a preliminary geomorphological assessment of the park to determine the potential of finding buried prehistoric archaeological sites by describing and interpreting the Quaternary alluvial stratigraphy. The second stage involved a pedestrian survey and shovel testing of an unimproved access road located north and west of the ruins, and an area adjacent to and west of the Stage 1 area (Figure 1). A total of 25.2 acres was surveyed and shovel tested during the two-stage investigation. The work was accomplished in 57 person days with a minimum field crew of three and a maximum field crew of seven. Robert J. Hard and C. Britt Bousman served as principal investigators; Maureen Brown acted as project archaeologist during Stage 1 investigations, and Diane Cargill during Stage 2.

\section{Project Location}

The Rancho de las Cabras site lies approximately five kilometers southwest of Floresville at the confluence of Picosa Creek and the San Antonio River in Wilson County, Texas (Figure 1). The project area includes Rancho de las Cabras, a unit of the San Antonio Missions National Historical Park, and a privately owned tract of land west of the ruins (Figure 1). The project area, investigated by pedestrian survey and shovel testing, is comprised of two areas separated by approximately $300 \mathrm{~m}$ (Figure 1). The southern tract area (west of the ruins) includes both the location of Stage 1 and part of the Stage 2 investigations. This area is located at Universal Transverse Mercator (UTM) coordinates N 3218220 through N 3218660 , and E 580810 through E 581000 . The northernmost area (access road), surveyed and tested during the Stage 2 investigation, has UTM coordinates of N 32 18 260-N 32 19 000, and E 579 960-E 580820 . The project area is located on the USGS 7.5' series Dewees Quadrangle map.

\section{Environment}

\section{Environmental Setting}

The Rancho de las Cabras site is situated in the Post Oak Belt subregion of the Central Gulf Coastal Plain physiographic region (Black 1989a). The project area is located on a high bluff overlooking the San Antonio River and Picosa Creek confluence in the Tertiary coastal plain of south-central Texas.

\section{Climate}

The climate for Wilson County is classified as subtropical with humid, hot summers and mild, dry winters (Taylor 1977:95). Annual rainfall is 28.96 inches with the months of late spring and early fall having the highest monthly rainfalls. Temperatures range on an annual basis from below freezing to over $100^{\circ} \mathrm{F}$, with an annual daily average of $81.9^{\circ} \mathrm{F}$ (Taylor 1977:94-95).

\section{Geology}

In the project area, the San Antonio River is confined to a valley constriction formed by a high bluff consisting of an outcrop of the Weches Formation (Figure 2). The Weches Formation is Eocene in age and consists of pale green to yellowish brown glauconitic sands interbedded with clay and silt (Barnes 1983). The Eocene Queen City Sand outcrops to the north of the Weches Formation, and the Sparta Sand outcrops to the south (Figure 2). The Weches 
This page has been

redacted because it

contains restricted

information. 


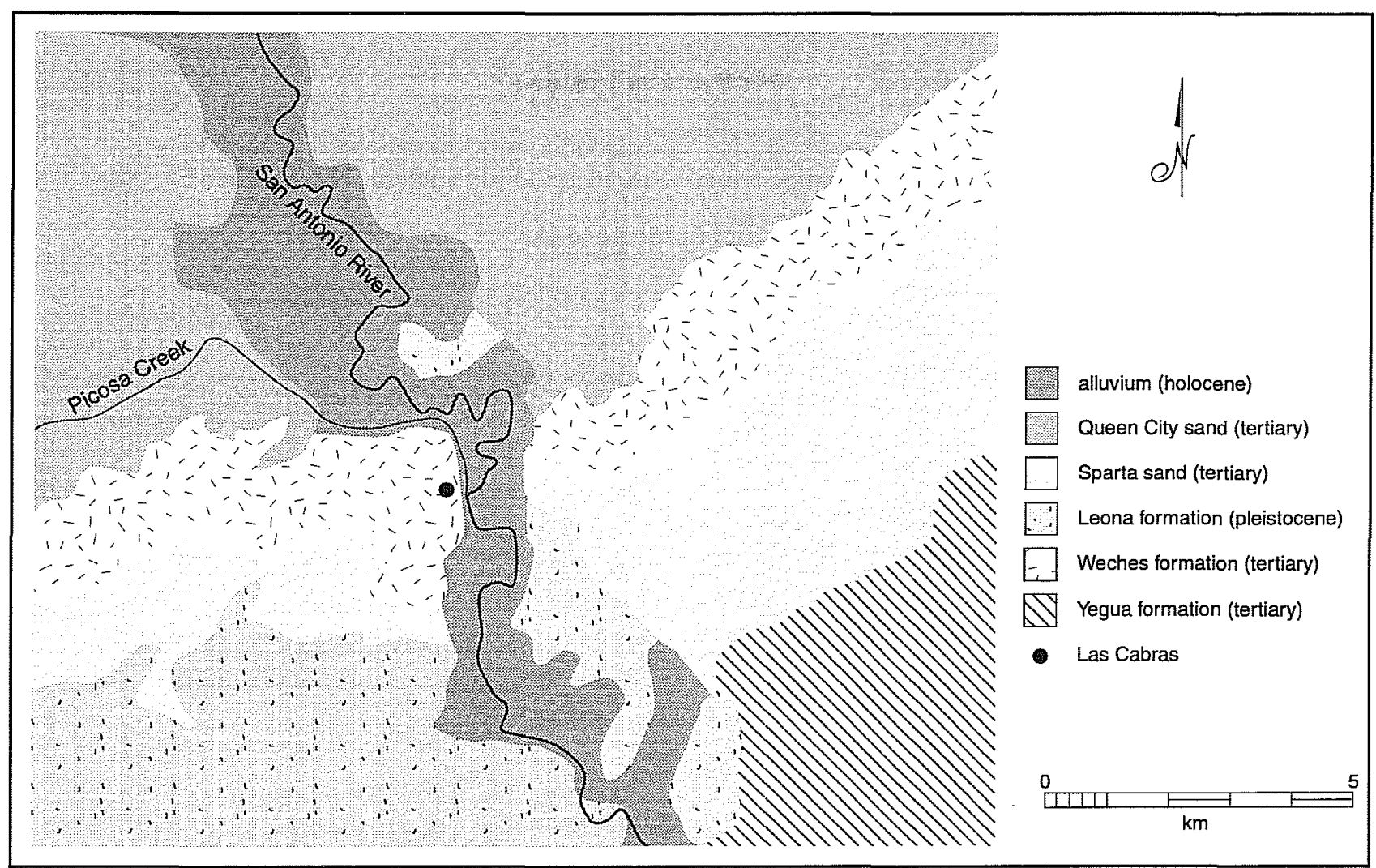

Figure 2. Geologic map of the project area. After Barnes 1983.

Formation was created in a marine environment. The Queen City and Sparta are continental deposits.

The oldest Quaternary deposit mapped in the area is the Leona Formation (Barnes 1983). The Leona is mapped as the first valley terrace of the San Antonio River approximately five kilometers south of the project area (Figure 2). It is assumed to be middle to early Pleistocene in age and consists of unconsolidated gravel, sand, silt, and clay of fluvial origin.

Quaternary alluvium is mapped along the entire floodplain of the San Antonio River within the project area (Figure 2). These deposits are thought to be Pleistocene in age, yet younger than the Leona Formation (Barnes 1983). No alluvial deposits are mapped along Picosa Creek.

The San Antonio River begins on lower Cretaceous limestones and clays to the north of the city of San Antonio along the Balcones Escarpment. The San Antonio River in the project area is a mixed-load, meandering stream (Figure 2). The Picosa Creek basin begins on the Queen City Sand northwest of the project area. The lower part of the creek flows across the Weches Formation before entering the San Antonio River (Figure 2).

\section{Soils}

The most commonly mapped soil series on the Weches Formation in the project area are Colibro (Ustochrepts, fine), Saspamco (Ustochrepts, fine), Wilco (Paleustalfs, fine), Coy (Argiustolls, fine), Elmendorf (Argiustolls, fine), and Floresville (Paleustalfs, fine) (Taylor 1977). Most of these soils (Wilco, Coy, Elmendorf, and Floresville) are mapped on stable upland landscape positions and exhibit morphological characteristics indicative of at least a Pleistocene age (Nordt 1996, 1997). These four soils are classified as Alfisols or Mollisols with clay-rich subsoils and common accumulations of secondary carbonate nodules. Two upland soils (Colibro and Saspamco) are Inceptisols and these may represent soils that have formed on recently eroded surfaces. 
The soils series within the broad alluvial valley of the San Antonio River are mapped primarily as Venus (Calciustoll, fine-loamy), Karnes (Ustochrept, coarseloamy), and Aransas (Haplaquoll, fine) (Taylor 1977). These soils usually exhibit considerably less pedogenic development than the upland soils. They are classified as Mollisols and Inceptisols with minor accumulations of secondary carbonate. These soils are indicative of Holocene ages (Nordt 1996, 1997). This is inconsistent with the mapping of Pleistocene alluvium in the San Antonio River valley (Barnes 1983).

Within the entrenched modern valley of the San Antonio River, the Loire-Frio, frequently flooded soils are mapped (Taylor 1977). These soils are classified as Ustifluvents (Loire) and Haplustolls (Frio). They are weakly developed Entisols and Mollisols typical of a late Holocene age (Nordt 1996, 1997).

\section{Flora}

The project area lies within the Tamaulipan Biotic Province region of south Texas (Blair 1950). Many of the modern-day floral communities prevalent in the area-including acacia, oak, ash, juniper, and spiny hackberry-appear to have been in the region for much of the Holocene (Labadie 1988:7). The mesquite chaparral of modern south Texas is the product of the many environmental exploitations that have occurred since the arrival of the first Europeans (Labadie 1988:7). Today in the project area, mesquite occurs along with thorny brush in the upland areas and the lands that have not been cleared for pasture (Ivey and Fox 1981:3). This type of secondary vegetation occurs in the land surrounding the Rancho de las Cabras ruins (Figure 3). In recent years this land was used for cattle grazing by the former owner, Winston Southern (personal communication 1997). The privately owned fields adjacent to the park are currently used for pasture and agriculture (Figure 4). The NPS access road is maintained for vehicular access into the park.

\section{Fauna}

The modern animal species common to this region include 61 species of mammals, 36 types of snakes, 19 lizard species, and a variety of frogs and turtles (Blair 1950). Steele and Assad Hunter (1986) suggest the fauna typical of the Tamaulipan biotic community has existed in the region for the last 2,000 years and identify additional pre-European animals including wild turkey, alligator, opossum, pronghorn, bison, white-tailed deer, peccary, bobcat, jack rabbit, and cottontail rabbit.

\section{Cultural Chronology}

\section{Paleoindian}

The Paleoindian period in South Texas spans approximately 3,200 years, from 11,200 to 8000 B.P. (Black 1989b). Clovis and Folsom projectile points,

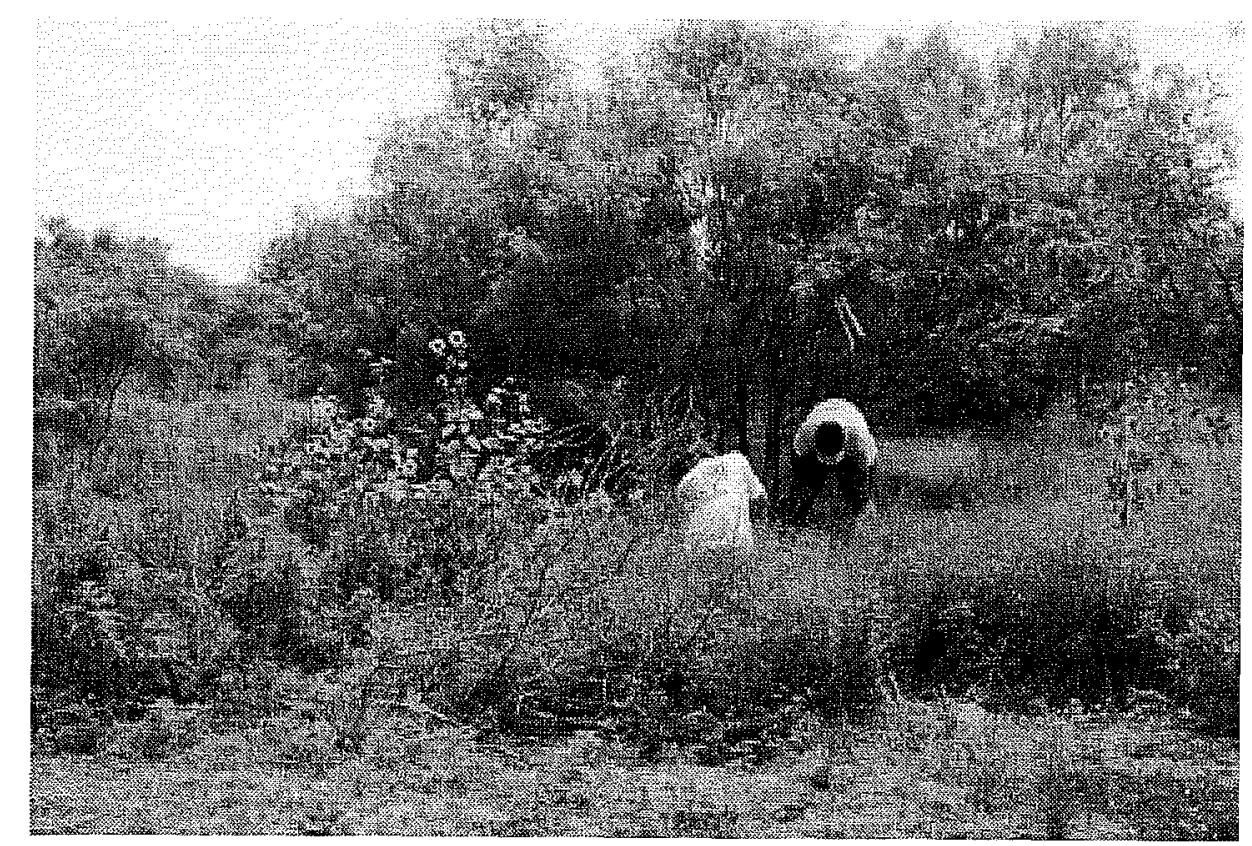

Figure 3. Secondary vegetation near the ruins. Stage 1 archaeological testing. 


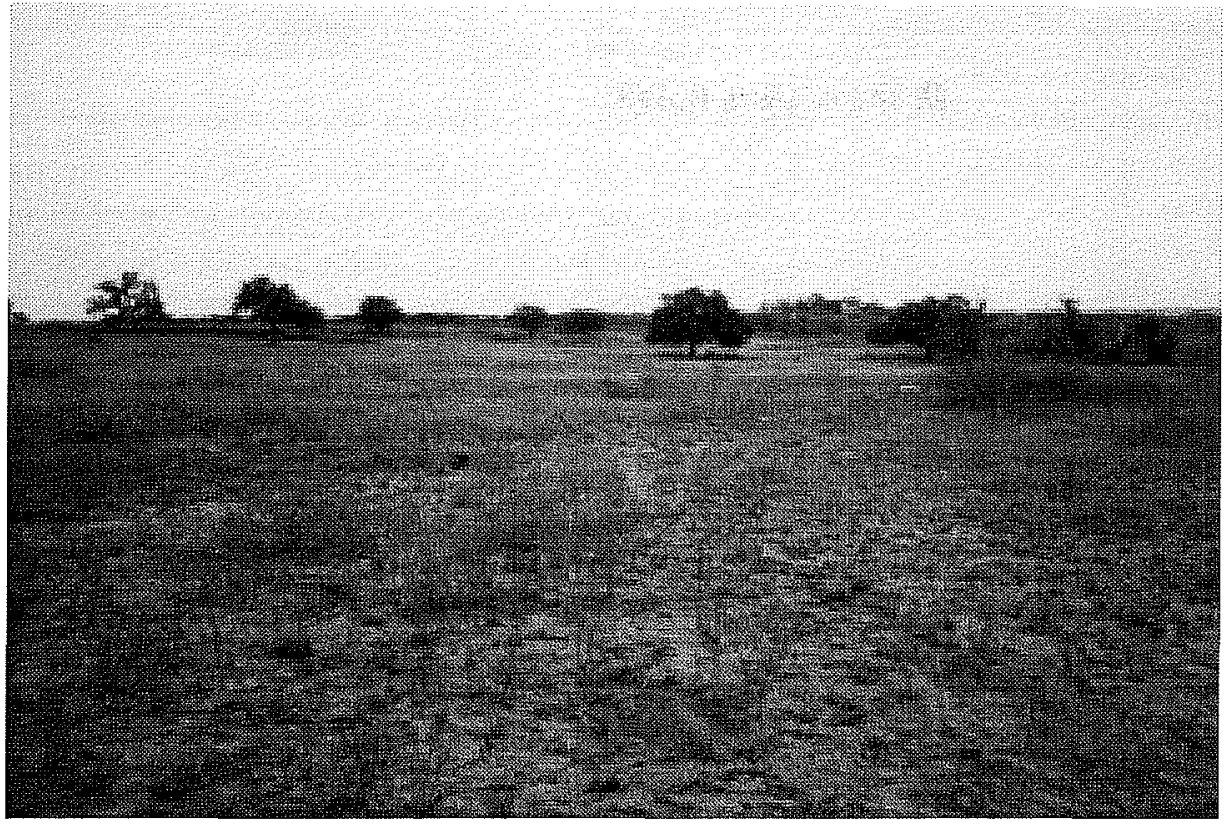

Figure 4. Southern tract pasture. Stage 2 archaeological testing.

both attributable to the earliest occupants of the New World, have been recovered from South Texas (Hester 1995). Postdating Clovis and Folsom, later Paleoindian projectile points known as Plainview, Golondrina, Scottsbluff, and Angostura have also been found in South Texas. Other lithic artifacts recovered from this time period are bifacial Clear Fork tools and finely flaked end scrapers (Black 1989b).

Paleoindian society probably consisted of small bands of people having large hunting and foraging territories and low population densities (Black 1989b). Early Paleoindians have typically been described in the archaeological literature as nomadic, specialized biggame hunters in pursuit of now-extinct Late Pleistocene fauna such as mammoth and Bison antiquus (Black 1989b). With the extinction of these species, a specialized hunting strategy continued through the Late Paleoindian period, but the target of prey shifted to other large herbivores such as Bison bison and deer (Odocoileus). As more data on early Paleoindian subsistence is recovered, however, the perception of big game hunters is giving way to "well-adapted, generalized hunters-gatherers with the technology to hunt big game but not the need to rely exclusively on it" (Collins 1995:382).
In South Texas, diagnostic projectile points of the Paleoindian period are usually recovered from the surface as isolated finds. Very few Paleoindian sites have been recorded. When documented, these sites are typically located on high terrace or upland locations (Black 1989b). Cultural material recovered from the Berger Bluff site in Goliad County indicate that the occupants exploited a range of small mammals, reptiles, and amphibians (Hester 1995). Eight radiocarbon samples from this site produced an average date of 9500 B.P., although no diagnostic projectile points were recovered from the deeply buried deposit (Hester 1995:435).

\section{Early Archaic}

The Early Archaic period in South Texas spans 3,500 years, from approximately 8000 to 4500 B.P. (Black 1989b). Projectile points diagnostic of this period include corner-notched dart point types like Martindale, Uvalde, Baker, and Bandy, and basalnotched point types such as Bell and Andice (Hester 1995). Early Triangular bifaces, Guadalupe tools, and Clear Fork tools comprise part of the Early Archaic lithic inventory (Hester 1995).

Early Archaic sites are uncommon in South Texas, however, their appearance is typically associated with high terrace or upland locations (Black 1989b). Deeply buried Early Archaic components have been documented at Choke Canyon in Live Oak County (Scott et al. 1982). Subsistence data from Early Archaic occupations is scant; however, freshwater mussel, Rabdotus snails, turtle, and freshwater drum were recovered from 41LK31/32 at Choke Canyon (Hester 1995). Thus the generalized hunting and gathering strategy of the Late Paleoindian period was 
probably maintained by the occupants of the Early Archaic period (Black 1989b). Population density is believed to have remained low, and Early Archaic inhabitants probably maintained large hunting and foraging territories (Black 1989b).

\section{Middle Archaic}

The Middle Archaic period in South Texas dates from roughly 4500 to 2400 B.P. (Black 1989b). Projectile point types characteristic of this cultural period include Pedernales, Langtry, Kinney, and Bulverde (Black 1989b). In the Coastal Bend area, Matamoros, Palmillas, Morhiss, and Bulverde points are commonly found (Black 1989b). Hester (1995) reports, however, that the triangular dart points of Tortugas and Abasolo dominate the Middle Archaic projectile point assemblage. Other cultural material recovered from Middle Archaic contexts include distally beveled unifacial and bifacial tools, tubular sandstone pipes (Hester 1995), grinding slabs, manos, incised bone, conch columela gouges, and conch adzes (Black 1989b).

Middle Archaic sites are found in a variety of environmental settings including uplands; along former and present stream channels; and in alluvial locations such as floodplains, low terraces, and natural levees of present stream courses (Hester 1995). Population is thought to have increased during this time based on an apparent increase in the number of sites and the presence of burned rock accumulations. The use of cooking stones is interpreted to be a direct result of the reliance on and processing of plant resources (Black et al. 1997). Other resources exploited during this time period include land snails, freshwater mussels, deer, and other mammals (Black $1989 \mathrm{~b}$ ). The initial appearance of large cemeteries located both inland and on the coastal plain suggests population increase, and that territorial ranges of hunters and gatherers are more restricted during the Middle Archaic (Black 1989b).

\section{Late Archaic}

The Late Archaic period in South Texas spans 1200 years from approximately 2400 to 1200 B.P. Projectile points distinctive of this period include Ensor, Frio, Marcos, Fairland, and Ellis (Black 1989b). In addition to the Ensor and Fairland types, Darl, Catan, and possibly Matamoros dart points are found in the Coastal Bend area (Black 1989b).

Late Archaic sites are common in South Texas in various environmental settings (Black 1989b). Accumulations of burned rock, first noted in the Middle Archaic, continue into the Late Archaic. Subsistence data suggest that Late Archaic hunters and gatherers exploited a wide range of small animals; however, plant resources may have comprised a major part of the diet (Black 1989b). If site density is a reliable indicator of population density, Late Archaic population was at an all-time high, relative to the preceding time periods (Black 1989b). The use of cemeteries continued in the Late Archaic period (Black 1989b).

\section{Late Prehistoric}

The Late Prehistoric period spans 800 years from approximately 1200 to 400 B.P. (Black 1989b). This period is further subdivided into two horizons, the Austin (1200-600 B.P.) and the Toyah (ca 600-300 B.P.). Ceramics and arrow points are distinctive of the Late Prehistoric period. Characteristic arrow point types include Edwards, Scallorn, and Perdiz.

Late Prehistoric period sites are numerous in South Texas, and occupation sites are typically found within $50 \mathrm{~m}$ of a dependable water source (Black 1989b). High population densities during the Late Prehistoric in South Texas are inferred by the presence of numerous archaeological sites (Black 1989b). Analyses of faunal remains demonstrate the exploitation of numerous species. Such remains from eight Late Prehistoric occupation sites in Dimmit, Zavala, and Jim Wells counties show aboriginal exploitation of 41 faunal species (Hester 1975). These include large mammals such as bison, antelope, and deer; mediumsize mammals such as bobcats, grey fox, and grey 
wolf; and small mammals such as skunk and raccoon. Different species of rodents, fish, amphibians, reptiles, and birds, as well as freshwater mussel, land snail, hackberry seeds, and acorns were also recovered (Hester 1975).

The Toyah horizon-characterized by Perdiz points, beveled knives, small end scrapers and ceramicshas been interpreted as representing a subsistence strategy based on bison hunting (Black 1989b). However, the relative importance of bison remains at these sites has been questioned. Black (1989b:32) for example, states that "most Toyah sites with faunal materials do indeed have bison bones"; however, careful faunal analysis conducted on materials from the Toyah component of the Panther Springs and Hinojosa sites indicate that deer were more prevalent than bison. Late Prehistoric sites along the coast demonstrate the exploitation of numerous marine resources taken from the bays, lagoons, offshore islands, and the Gulf of Mexico; as well as terrestrial mammals and reptiles taken from the adjacent prairie (Hester 1981).

\section{Historic}

Spanish exploration of Texas began in the early sixteenth century when Cabeza de Vaca and De SotoMoscoso are both thought to have been in the vicinity of present-day San Antonio around 1535 (Sanchez 1992) and the 1540s (Bruseth 1992) respectively. It was not until 1684, however, that the northern frontier of Tejas became an important consideration for Spain, brought about by the French presence in East Texas (Bannon 1979). Subsequently, several Spanish missions were constructed in the late-seventeenth and early- to mid-eighteenth centuries in east, central, and south Texas.

The goal of a mission was to Hispanicize and Christianize the indigenous people and ultimately to create loyal Spanish subjects. When this goal was successful, it created a safe haven for subsequent colonization and future expansion. A mission was to be as self-sufficient as possible (Ivey 1991), which meant having a church, sacristy, convento, weaving room, workrooms, storerooms, granaries, and the native pueblo; along with stonemason, blacksmith, and carpenter shops (Ivey 1984). Located outside this complex were the mills, agricultural fields, dams, acequias (irrigation ditches), aqueducts, grazing fields, and mission ranches. Apparently, the mission ranches were not part of the original plan of a mission as "none of the [San Antonio] missions were established with their later ranch lands included in the original grant" (Ivey 1991:1). The later addition of mission ranches was a result of the secular encroachment into mission areas previously deemed and legally required as "empty lands" (Ivey 1991:4).

Rancho de las Cabras was a livestock ranch belonging to Mission Espada. During the mission's early years (1731-1737), cattle were obtained from the Queretaran missions of the Rio Grande (Ivey 1991). Given the large number of livestock reported in 1745, Ivey (1991) suggests that large-scale ranching activities began about 1740 . Although the land grant issued to Mission Espada for Rancho de las Cabras has never been found, the ranch is thought to have been "officially" acquired ca. 1765 (Ivey 1983). Rancho de las Cabras is first referred to by Fr. Mariano Dolores in 1762 as a ranch belonging to Mission Espada (Fox 1989). He describes it further as a "una casa de piedra," a house or structure of stone, where the ranch hands and their families lived, and where all the tools and equipment were stored (Fox 1989). The first official mention of Rancho de las Cabras was in March 1772 in a lawsuit between the citizens of San Fernando de Bexar and the missions of the San Antonio river valley (Ivey 1983).

In 1772 a detailed inventory of Mission Espada, including Rancho de las Cabras, was conducted. The inventory was necessitated by an official change in administration of the Texas missions from the College of Queretaro to the College of Zacatecas (Fox 1989). Among other listings, the livestock was recorded as 1,200 cattle, 2,700 sheep, 716 horses, mules, and burros, 22 goats, 35 pigs, 8 oxen, and miscellaneous chickens (Fox 1989). Mission Espada was partially secularized in 1793 and it is assumed that the operation of Rancho de las Cabras by Mission Espada ended during this time (Fox 1989). Mission Espada was fully secularized in 1824. 
It may be that Rancho de las Cabras was originally called Rancho de el Sabinito (Little Juniper Ranch) (Ivey 1991). In a 1770 lawsuit between don Martin de la Peña and Mission Espada over ranch land, a reference is made to El Sabinito "with its fort of stone" (Ivey 1991). Ivey suggests that "up to about 1768 1770 the Espada ranch headquarters was called Rancho de el Sabinito, but after that date it was popularly known as Rancho de las Cabras, The Goat Ranch" (Ivey 1991:31).

The state of Texas initiated action to acquire the Spanish colonial site of Rancho de las Cabras (41WN30) on May 4, 1977. The acquisition was finalized on May 22, 1982 (218th Judicial District Court Records, Wilson County, Texas; case no. 9474) and 41 WN30 became a State Historical Park administered by the Texas Parks and Wildlife Department. In 1995, Rancho de las Cabras became part of the San Antonio Missions National Historical Park, and has since been managed by the National Park Service. A National Register Nomination was made in 1972 by the Texas State Historical Survey Committee, and Rancho de las Cabras is listed in the National Register of Historic Places and is designated a State Archeological Landmark.

\section{Previous Archaeological Investi- gations at Rancho de las Cabras}

In 1980 CAR conducted a survey and testing project at Rancho de las Cabras for the Texas Parks and Wildlife Department (TPWD). This was the first of five investigations carried out by CAR between 1980 and 1984. The goal of the first survey and testing project was to provide an initial assessment of the site to make plans for future archaeological work, and to delineate cultural and non-cultural resource areas to aid in the development plans of the park (Ivey and Fox 1981). The remaining four investigations included archival research and further testing of the ranch compound to provide the public with an archaeological and historical interpretation of a frontier mission ranch during the Spanish colonial period.

The cultural material recovered during CAR's five investigations demonstrates that Rancho de las Cabras was primarily occupied between 1760 and 1820 , and that this occupation is related to the ranch hands, and families who lived in the ranch compound. By employing excavation units, shovel tests, and trenches, archaeologists revealed several important features at the site. Prominent among these are an irregularly shaped stone walled compound; four rooms with stone wall construction adjacent to and inside the north compound wall; a chapel; two bastions, one extending from the southeast corner and the other extending from the northwest corner of the compound; a northwest gateway (later sealed); a lime kiln; four rooms of jacal construction, identified by jacal trenches and postholes; two original walls of the ranch compound, one located on the east and the other on the west side of the compound; and two trash middens, one located outside the east wall and the other outside the north wall of the compound (Figure 5). Less prominent, but just as important, features include postholes and sections of jacal trenches located in various areas of the interior compound, a possible well (interior compound), a possible lime-slaking pit (outside north wall of compound), a trench containing postholes which may have been a picket-type fence for a corral, a wall-like structure which intersects and extends west from the southwest corner of the compound, and areas of disturbance associated with treasure hunters.

Today the visible stone walls of the ranch compound have an irregular four-sided shape measuring roughly $35.5 \mathrm{~m}$ north/south and $30-58 \mathrm{~m}$ east/west. During the archaeological investigations, two original walls of the compound were exposed. Based on these two compound walls, an interior circumference of the earliest form of the enclosing wall is $133.9 \mathrm{~m}$. Similarly, the 1772 inventory reports a circumference of 158 varas or about $133.8 \mathrm{~m}$ (Ivey 1983). The fact that there is only a $10-\mathrm{cm}$ discrepancy between the 1772 inventory and CAR's measurements suggests that the two walls identified by CAR as original walls were indeed from the earlier, original construction.

The archaeological investigations demonstrate that the original stone wall enclosure did not include the chapel, the area east and south of the chapel, the small triangular area in the northwest, the two defensive bastions, and the four stone walled rooms. These were later additions and it is not known when they were 
constructed; however, it is surmised that this renovation occurred sometime between 1775 and 1780 (Ivey 1983).

Two additional occupations of this site, unrelated to the ranch, have been observed during the archaeological investigations conducted by CAR. Lithic artifacts and mussel shell recovered near the base of wall footings (approximately one meter below ground surface) are attributable to an early, pre-ranch period. Due to the lack of diagnostic lithic artifacts however, this component cannot be dated. The other occupation, represented by late-nineteenth- and early-twentiethcentury artifacts, indicates intermittent use of the area by local hunters, treasure hunters, picnickers (Ivey and Fox 1981), and various landowners who "continued to use the site for running livestock and probably briefly used the buildings for storage" (Fox 1997).

The eighteenth-century cultural material recovered at Las Cabras is identical to that found on mission sites in San Antonio (Fox 1997). At Las Cabras, bone and ceramics were the two most highly represented artifact classes. Of the ceramic class, Goliad ware was present in much higher numbers than any other ceramic type. Goliad ware is a hand-made, unglazed ceramic which was fired over an open campfire (Fox 1981). It was manufactured during prehistoric times and continued to be manufactured during the Spanish colonial period (Fox 1981). Numerous lithic flakes, tools, and several projectile points of the Guerrero type were also collected at Las Cabras. The presence of Goliad ware and stone artifacts reflects the Native American presence there (Ivey 1983).

A summary of the five previous field seasons is provided below.

\section{First Field Season-1980}

Fieldwork was carried out from late June 1980 to the end of July 1980. Since this was the first testing project at Las Cabras, little was known about the site, either archaeologically or historically. The emphasis was to determine the vertical and horizontal extent of the cultural deposits, identify architectural features and the type of materials used in the construction of the features, locate trash middens, and identify noncultural resource areas to be used in the future development of a visitors' center and access road to Rancho de las Cabras (Ivey and Fox 1981).

Three shovel tests (1-3), and 14 test units (Units 2-15) were excavated (Figure 5). Note that Unit 1 was established but not dug. Excavation units ranged in size from $1 \times 1 \mathrm{~m}$ to $2 \times 3 \mathrm{~m}$. Units were excavated by natural strata and screened through $1 / 4$-inch hardware cloth. The entire project area was surveyed and surface collected.

The 1980 investigation identified the following: standing sandstone block walls up to five and six feet high along the compound's north wall; a room designated as the chapel, an apparent northwest gateway, three rooms of stonewall construction located south of the north compound wall, and a possible trash pit north of the north compound wall. Various other features uncovered include a possible well, a section of a plaster floor, occupation surfaces of hard-packed tan clay, hearth features, postholes, a jacal wall trench, manure layers, and disturbed areas (presumably associated with pot hunters' backdirt). CAR and TPWD produced a map of Rancho De Las Cabras illustrating the compound walls, chapel, northern rooms, and excavation units. During the survey phase of the 1980 investigation, a limited number of prehistoric lithic artifacts was recovered. These artifacts were located mainly along the northern quarter of the northeastern fence line and are probably from an aboriginal site across the fence line to the northeast (Ivey and Fox 1981). Other chert fragments observed during the survey were determined to be a result of plow manufacture.

Cultural material in the form of ceramics, building materials, glass, metal, and stone objects recovered from the compound area point to a major occupation of the site from approximately 1760 to 1820 (Ivey and Fox 1981). Recovered faunal remains indicate that the occupants consumed both wild (e.g., squirrels, rabbits, turkey, javelina, fish, and turtles) and domesticated animals (e.g., cattle, goat/sheep, European pig, chicken). Ivey and Fox (1981) concluded that no significant occupation occurred after about 1810 . 


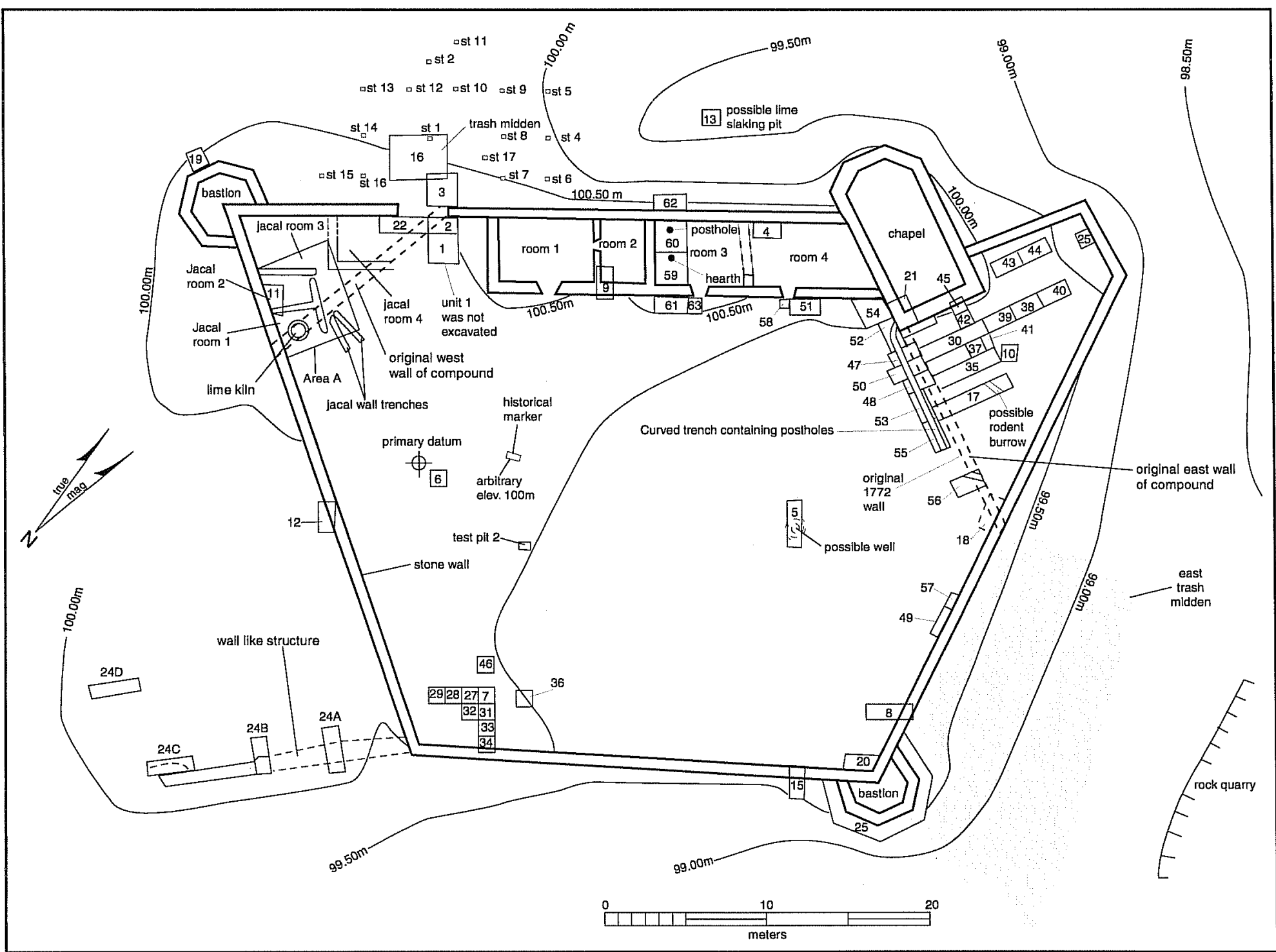

Figure 5. CAR's 1980-1984 archaeological investigations of Rancho de las Cabras. 


\section{Second Field Season-1981}

The second field season was conducted by CAR during July and August 1981. Archival research was performed concurrently with the fieldwork. The ranch compound, or headquarters for the ranching operation, had been defined by the end of the 1980 field season. The goal of the 1981 investigation was to further explore the compound area for evidence of cultural activity, architectural tracings, and stratigraphic sequences (Ivey 1983). Generally speaking, four areas became the focus of the 1981 field investigation: the northwest, southeast, and southwest areas of the compound; as well as the northeast corner of the compound (adjacent to, and east and south of the chapel).

The northwest area of the compound was investigated for activity areas, and other cultural traces within and outside the jacal wall trenches identified in 1980 (designated Area A). Additionally, the trash midden identified in 1980 was subjected to a more thorough investigation. Excavation units in the northeastern corner of the compound were dug to locate the front or facade of the chapel, gather architectural and stratigraphic information, check for the presence of an earlier compound wall noted in 1980 , and locate the position of the northeastern end of the north wall. In the southwest area of the compound, traces of a wall extending west from the southwest corner of the compound were observed and investigated.

Fourteen excavation units (16-25, 24A-D, and Area A) were dug during the 1981 field season (Figure 5). These units ranged in size from $1 \times 1 \mathrm{~m}$ to $5 \times 6 \mathrm{~m}$ (Unit Area A). Units dug for stratigraphic information were excavated by natural strata (including Unit Area A) and screened through $1 / 4$-inch hardware cloth. Units dug for the purpose of gaining architectural information were shoveled out and artifacts observed in the process were collected, but the soil was not screened (Ivey 1983).

The original east wall of the compound was identified during the 1981 investigation (Figure 5). Also observed was the intersection of the original east wall with the later addition of the new wall. A difference in the size and color of sandstone rock between the original and new walls was noted; however, time was too limited to further investigate this apparent difference (Ivey 1983). The front or facade wall of the chapel was identified. Also located in this area was evidence of a looters' pit. Layers of manure which were observed post-date the use of the chapel. Large stones were found lying on the occupation surface, indicating the decay of the church prior to manure accumulation. Two bastions were identified, one located in the southeast and the other in the northwest sections of the compound. Rubble was cleared until the tops of the wall remains were clearly defined (Ivey 1983). Bastion walls and all perimeter compound walls were $66 \mathrm{~cm}$ thick. An apparent wall-like structure was defined adjoining the southwest corner of the compound wall and extending west. Vertical and horizontal excavation was insufficient to determine the true nature of this wall-like structure. It appeared to have a very shallow foundation, if any, and no footing trench was observed. The excavation of the trash pit identified in 1980 demonstrated that not one, but at least four overlapping trash pits were present. The volume of the faunal material was too great and the remains (articulated bone) too informative to be recovered during the 1981 season, so this important source of information was covered and left for future investigation. Area A contained trenches and postholes comprising four separate jacal rooms, three hearths, occupation floors, a stone wall footing for the original compound wall, and a lime kiln.

The artifacts recovered from the 1981 investigation confirm that the main occupation of Rancho de las Cabras occurred between the years of 1760 and 1820 . Late-nineteenth- and twentieth-century occupation of the site (as reflected in artifact type and density) is interpreted to be the result of intermittent visits by local hunters, picnickers, and treasure hunters (Ivey 1983).

\section{Third Field Season -1982}

CAR returned to Rancho de las Cabras for a third season in June 1982. Both fieldwork and archival research were undertaken as part of this investigation. Based upon the results of the 1980 and 1981 investigations, the goals in 1982 were to continue 
testing within the compound's stone wall enclosure for evidence of construction and occupation activity, and to investigate the area adjacent to the chapel for the possible existence of burials (Jones and Fox 1983).

Twenty excavation units (Units 27-46) were dug in 1982 (Figure 5). These units ranged in size from $1 \times 1 \mathrm{~m}$ to $1 \times 4.4 \mathrm{~m}$ (Jones and Fox 1983). In addition, two $50-\mathrm{x}-75-\mathrm{cm}$ test pits were excavated. All units were excavated by natural strata using a trowel or shovel. The soil removed during trowel excavation was screened through 1/4-inch hardware mesh screens. Soil excavated by shovel was peeled off in thin layers and visually examined for cultural materials (Jones and Fox 1983).

Two areas within the compound walls were the focus of the 1982 field season. The northeast corner of the compound (south and east of the chapel) was selected for investigation to document the presence of burials. The southwest corner of the compound was chosen for further work because the 1980 and 1981 investigations demonstrated this area's potential for containing early construction information (Jones and Fox 1983).

Excavations at the southwest corner of the compound were unable to document early jacal structures in this area. Two overlapping postholes were revealed in Unit 34 , in line with the posthole documented in Unit 7 during the 1980 investigation; however, jacal wall trenches were not observed. These postholes may represent the remains of a ramada (arbor) or perhaps a livestock enclosure (Jones and Fox 1983). Furthermore, burials were not located in the northeast corner of the compound; however, structural and nonstructural features which both predate and postdate the construction of the chapel were documented. These features include postholes, a jacal wall trench, areas of disturbance (assumed to be related to looting activities), and a shallow basin-shaped pit.

Artifacts recovered during the 1982 field season are similar to those recovered during the previous two seasons and reflect the same types and time period (Jones and Fox 1983). Faunal remains recovered during this project indicate that a wide variety of both wild and domesticated animals were consumed by the inhabitants of Rancho de las Cabras. Recovered bone, by weight, indicates that cow provides the greatest representation ( 40 percent), followed by deer, goat, and sheep at 2.5 percent each, with the remaining species comprising less than .2 percent (McClure 1983). McClure (1983) notes that many of the domestic species were killed as subadults.

\section{Fourth Field Season-1983}

CAR conducted its fourth investigation at Rancho de las Cabras in July 1983. Both fieldwork and oral histories were conducted as part of this project. Based on the results and archival research provided by the previous three investigations, the goals of the 1983 project included documenting the history of construction and sequential relationship between the chapel and the rooms located inside the north wall adjacent to the chapel, determining the location of the second gate/entrance of the compound, and conducting oral history interviews of area residents (Fox 1998). In addition, the original east wall of the compound was tested to locate the footing trench for this wall and to determine if postholes or jacal trenches were present west of the original wall. Previous investigations had identified postholes and jacal trenches east of the original east wall and it was thought that they may continue to the west.

Twelve excavation units (Units 47-58) were dug by natural strata in the east part of the compound (Figure 5). Units ranged in size from $50 \times 50 \mathrm{~cm}$ to $1 \times 2 \mathrm{~m}$. Excavated material was screened using $1 / 4$-inch hardware cloth; however, many of the strata were shoveled out and not screened. Five area residents were interviewed for their oral histories concerning Rancho de las Cabras.

The results of the field investigation demonstrate that the south wall of Room 3 (adjacent to the chapel) was constructed after the chapel's west wall. However, the west wall of the chapel is part of the original east wall of the compound, so it is still not known if the chapel and the rooms adjacent to the chapel were constructed at the same time. In addition, a doorway was identified along the south wall of Room 3. Excavation units placed along the original east wall of the compound 
identified a curved trench containing postholes (Fox 1997). This trench is believed to have been part of a picket-type fence probably used as a corral. The second gateway or entrance was not located during this investigation.

Artifacts recovered during the 1983 investigation support the same chronological patterning observed during the previous three investigations. The period of continuous occupation appears to have occurred between ca. 1750 and 1820 when the ranch was controlled by the mission. Intermittent use of the site occurred during the nineteenth and twentieth centuries. The later use of the site appears to have involved the running of livestock, storage, picnicking, and treasure hunting (Fox 1997; Ivey 1983). Recovered faunal remains show a representation of both wild and domesticated species similar to the previous three investigations. However, analysis beyond species identification was not conducted, so relative representation cannot be addressed.

\section{Fifth Field Season-1984}

CAR returned in late May and June 1984 to conduct the last of five field investigations sponsored by the TPWD. As part of this project, archival research was conducted by Dr. Thomas N. Campbell, professor emeritus of the Department of Anthropology, The University of Texas at Austin. The goals of the 1984 investigation included systematic shovel testing of the north midden to determine its vertical and horizontal extent, testing of the easternmost stone room located along the north compound wall, and excavation of the south wall of stone rooms located along the north compound wall in order to determine the location of doors and windows (Taylor and Fox 1985).

Fourteen shovel tests (Units 4-17) were dug in the north midden area; several hand-dug trenches were excavated along both faces of the east, south, and west walls of the four stone rooms; and five units (Units 59-63) were dug inside and outside of Room 3 (Figure $5)$. Shovel tests were not dug by levels. All cultural material collected from the $1 / 4$-inch screen from each shovel test was bagged together. Shovel test depth ranged between 22 and $86 \mathrm{~cm}$, and most shovel tests reached culturally sterile soil. Trenches were approximately $25 \mathrm{~cm}$ wide and $40 \mathrm{~cm}$ deep, and trench fill was not screened. Units ranged in size from $1 \mathrm{x} 1 \mathrm{~m}$ to $2 \times 2 \mathrm{~m}$ and were excavated by natural strata. Wall fall rubble and backfill from looters' pits was not screened, however, all remaining matrix removed during the excavation of units was screened through 1/4-inch hardware cloth.

The 1984 investigation exceeded its goals and was able to provide additional data on the historic site of Las Cabras. A selective surface collection of a midden east of the east compound wall indicates that this deposit dates to the same period as the north midden, that of the mid 1700s (Taylor and Fox 1985). Shovel tests excavated in the north midden demonstrate that this feature deposit may have a limited horizontal distribution. None of the shovel tests, with the exception of ST 7, encountered the north midden deposits observed in 1981 (Taylor and Fox 1985). Excavation units placed outside the north compound wall of Room 3, inside Room 3, and adjacent and south of Room 3 (in the plaza area) were excavated to provide a continual profile of the deposits, thereby supplying additional information on the stratigraphic and construction sequence in the north compound area (Taylor and Fox 1985). What was once thought to be a single room (Room 3), was determined to actually comprise two rooms. This new discovery results in a total room count along the north compound wall of four rooms, rather than the three reported in 1983.

The majority of cultural material recovered during this investigation dates from ca. 1760 to 1820 . Most of the ceramic sherds are Goliad ware. Lithics and mussel shell, however, were recovered beneath the compound occupation surface and predate the site of Rancho de las Cabras. Due to a lack of diagnostic lithic material, this earliest occupation of the site cannot be dated (Taylor and Fox 1985). Recovered faunal material from this field season is comprised mostly of unidentifiable bone fragments (Steele and DeMarcay 1985). However, several taxa are represented, and Steele and DeMarcay (1985) provide an inventory of each by time period (i.e. pre-ranch, ranch, and postabandonment of the ranch). Dietary patterns observed include the presence of small fauna in the pre-ranch deposits, and large domestic species of cow, 
goat, and sheep in the deposits representative of the ranch and post-use of the ranch. During the historic period, deer, turtles, alligators, fish, and birds are present, and "the number of elements of fish particularly suggests that these may have been commonly taken from the nearby San Antonio or other water sources" (Steele and DeMarcay 1985:66). A large proportion of the cow, sheep, and goat were apparently killed as subadults. It is suggested that young and tender animals are selected when there are plenty of animals from which to choose (Steele and DeMarcay 1985). This is a pattern also observed by McClure (1983) in his analysis of the faunal material recovered during the 1982 investigation at Rancho de las Cabras.

\section{Methodology \\ Geomorphological Methods}

Following the standards and procedures of the Soil Survey Division Staff (1993) and Folk (1980), Lee C. Nordt of Baylor University described the soilstratigraphic profiles based on the four observed alluvial units in the project area. A geomorphic map (Figure 6) was constructed based on a one-foot contour interval topographic map provided by the U.S. Department of the Interior (1997), the local soil survey (Taylor 1977), the local geologic atlas (Barnes 1983), and local USGS topographic maps.

The geomorphic map was intended to display the maximum possible extent of late Quaternary alluvial deposits. The diagnostic terrace tread and riser is absent in most areas west of the San Antonio River. Thus, the boundaries for the alluvial landforms in this area were estimated based primarily on elevation above river level and associated gully knickpoints. Parts of these landforms may consist of erosional hillslopes. To the east of the San Antonio River the alluvial terraces are more apparent. Further field reconnaissance is needed to reject or verify the geomorphic map, particularly on the west side of the project area.

\section{Archaeological Field Methodology—Stage 1}

Stage 1 archaeological investigations included a pedestrian survey and intensive shovel testing to document the presence of subsurface cultural material within NPS land just west of the Rancho de las Cabras ruins (Figure 1). A 75-x-225-m area was laid out using tape and compass. Thirty-two shovel tests were excavated within this grid at $25-\mathrm{m}$ intervals (Figure 7). The shovel tests were approximately $30 \mathrm{~cm}$ in diameter and were excavated in 10-cm arbitrary levels to a maximum depth of $50 \mathrm{~cm}$ below surface (bs). All soils were screened through a $1 / 4$-inch wire mesh, and all artifacts were collected. Standard CAR shovel test forms that include artifact and soil descriptions were completed for individual shovel tests. Photographs were taken using a Pentax K-1000 35-mm camera using color print film. All cultural material was taken to the CAR laboratory for processing (see Laboratory Methods).

\section{Archaeological Field Methodology—Stage 2}

Pedestrian survey and shovel testing of the southern tract and access road (Stage 2) was conducted in the following manner: survey was accomplished in a systematic five-meter interval and shovel testing was done every $30 \mathrm{~m}$ across the project area. Forty-two survey transects and 63 shovel tests were performed in the southern tract (Figure 7). Five survey transects and 35 shovel tests were conducted in the NPS access road right-of-way (Figure 8).

During the pedestrian survey, cultural material was recorded by each archaeologist on his or her transect and artifacts were tagged with flagging tape. Upon completion of the survey, CAR archaeologists returned to areas containing cultural material to determine whether or not the observed artifacts constituted an archaeological site. Large sites have a density of 20 artifacts or greater within a $25-\mathrm{m}^{2}$ area, and/or are 100 $\mathrm{m}^{2}$ or larger in size, and/or contain two or more cultural features. Small sites have a density of 5-19 artifacts within a $25-\mathrm{m}^{2}$ area, and are less than $100 \mathrm{~m}^{2}$ in size, and contain no cultural features (Hard et al. 1996). Sites, concentration areas within sites, and special collections within sites were plotted and mapped. 


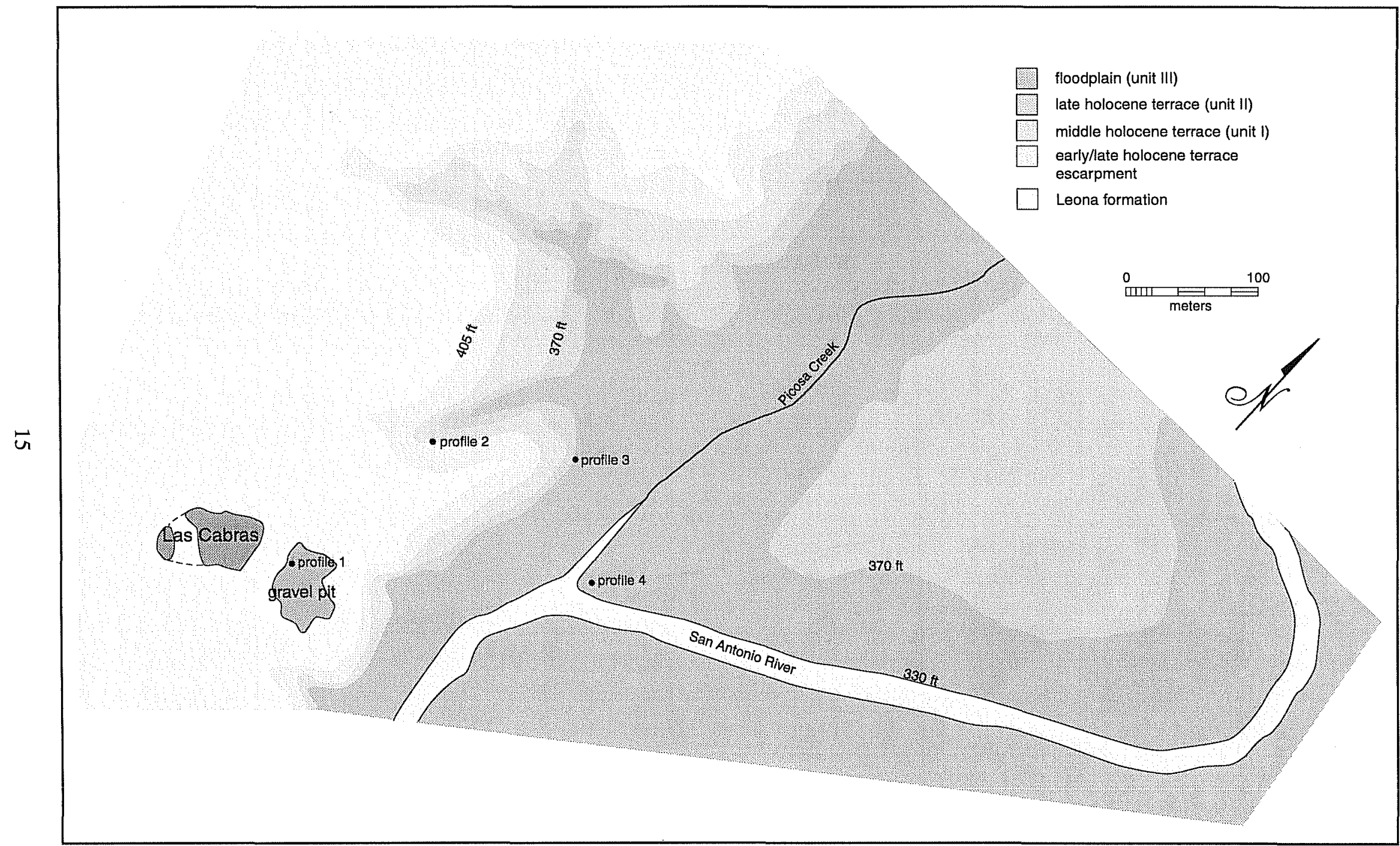

Figure 6. Landform map of the project area showing the potential distribution of late Quaternary deposits, profile locations, and selected elevations. 


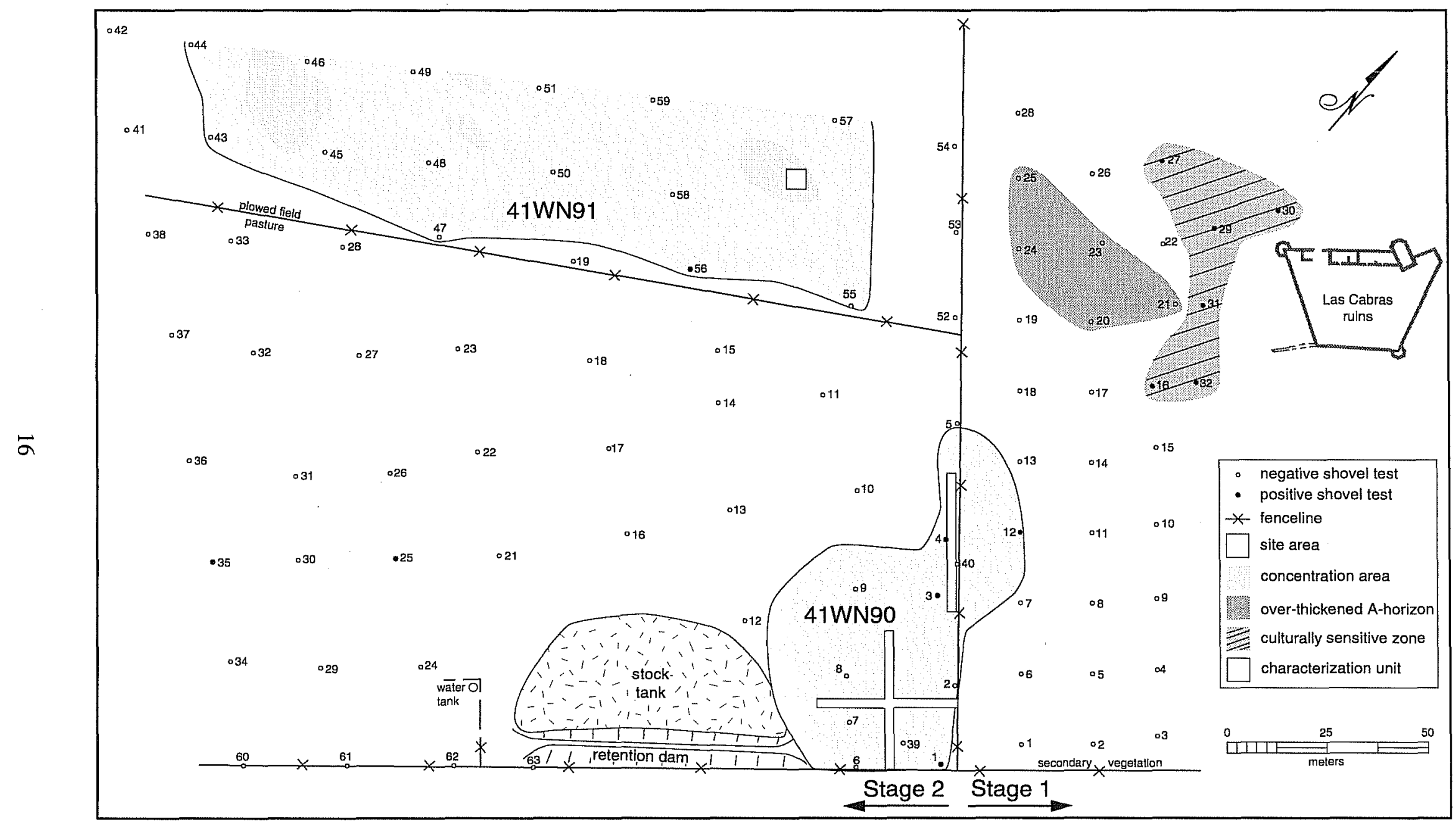

Figure 7. Stage 1 and 2 archaeological survey and testing, shovel test locations, 41 WN90 and 41 WN91 site boundaries, characterization units, and concentration areas. 


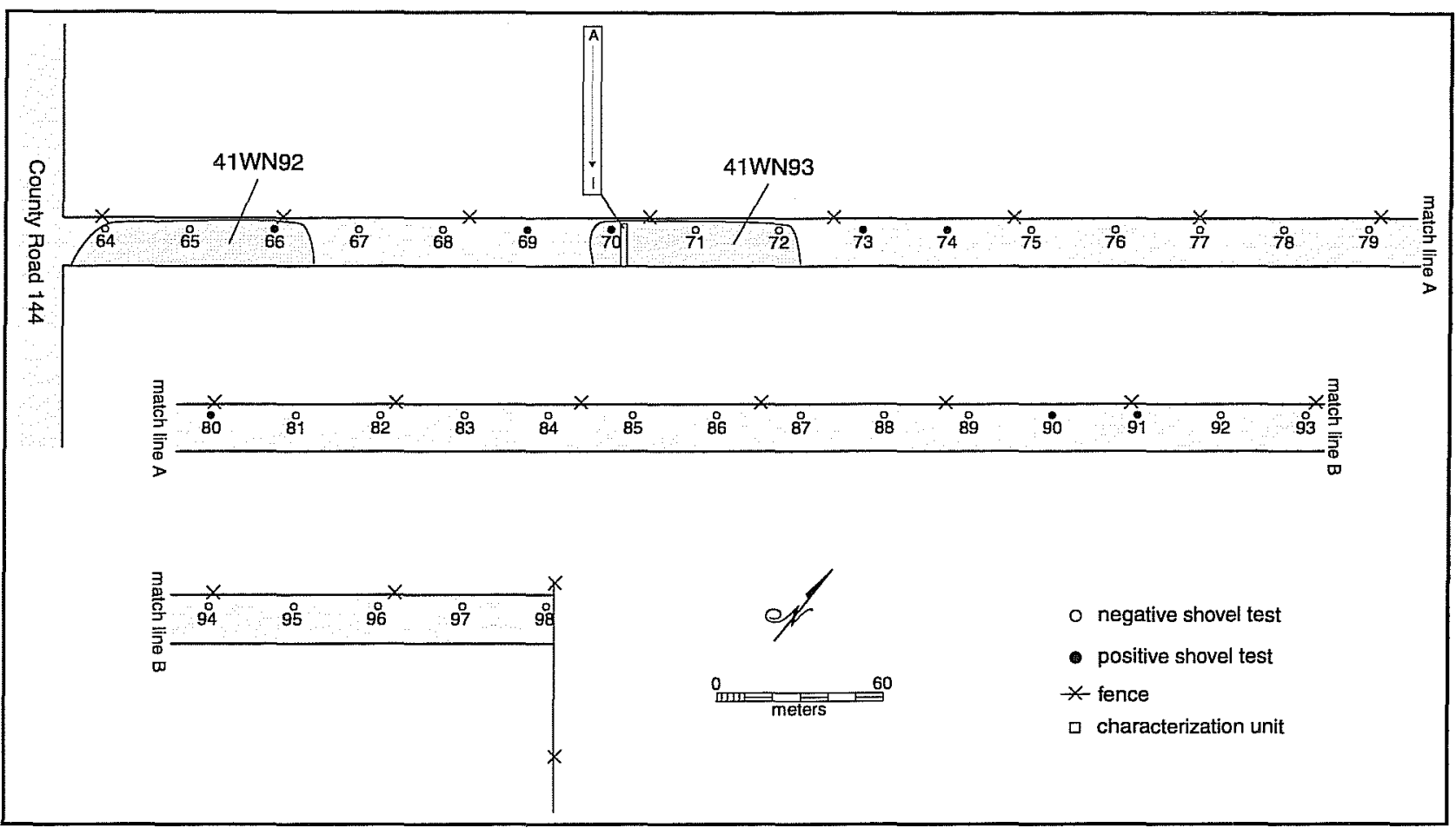

Figure 8. Stage 2 access road, shovel test locations, and 41 WN92 and 41WN93 site boundaries, characterization units, and concentration areas.

The NPS requested that CAR conduct characterization units on identified sites to evaluate variation in artifact density within each site. This type of sampling was necessarily judgmental and the project archaeologist decided the placement, size, and number of characterization units conducted at each site. Characterization units varied in size between $1 \times 1 \mathrm{~m}$ and $3 \times 3 \mathrm{~m}$, and the placement of the units was designed to sample high, medium, and low artifact densities within each site boundary. All artifacts within the prescribed units were collected and returned to the CAR laboratory for analysis.

Forty-four 3-x-3-m characterization units (Units A-RR) were placed within the boundaries of site 41WN90 (Figure 7). Units A-HH were located in the southern half of the site in a cruciform shape, and Units II through RR were placed in a linear line running north/south in the northern part of the site. Twentyfive $1-\mathrm{x}-1-\mathrm{m}$ characterization units (Units $\mathrm{A}-\mathrm{Y}$ ) were placed within site 41WN91 in the form of a grid (Figure 7). They were placed to sample artifact density adjacent to and within Concentration Area 1. Nine 3-X-3-m characterization units (Units A-I) were placed across site 41WN93 in a linear line running north/ south (Figure 8). The extremely low artifact density at site 41WN92 precluded the need for characterization units at this site. Careful surface observation indicated that characterization units would yield only one or two artifacts.

The 98 shovel tests were approximately $30 \mathrm{~cm}$ in diameter and excavated in 10-cm arbitrary levels. The exception to this method occurred within the plowed field. Here the first level (Level 1) was excavated as a 20 -cm level since it was reported that the upper seven inches $(20 \mathrm{~cm})$ was the plow zone and cultural material was in a disturbed context. Shovel testing was conducted to test the subsurface to a depth of $50 \mathrm{~cm}$ bs for the presence of cultural materials. Ninety-two of the 98 shovel tests were dug to this depth. Six shallower tests were the result of encountering soils and cobbles so hard and compact that to reach a depth of $50 \mathrm{~cm}$ bs required more than a shovel and a handheld pick-axe. Three of the six shovel tests reached a depth between 40 and $50 \mathrm{~cm}$ bs and three were dug to a depth between 30 and $40 \mathrm{~cm}$ bs. All soil matrix was screened through 1/4-inch wire mesh and all cultural 
material was collected. Shovel test information (e.g., artifacts collected and observed, soil texture and color) was recorded on standard CAR shovel test forms.

The two archaeological sites and shovel tests located in the southern tract (41WN90 and 41WN91) were mapped by CAR staff using a Total Data Station. The two sites and shovel tests located within the access road (41WN92 and 41WN93) were mapped by pace and compass.

Photographs were taken with a Canon Sure Shot camera using color print/slide film. All photographs were recorded on standard CAR forms. Recovered cultural material was processed at the CAR laboratory.

\section{Laboratory Methods}

Cultural material for both Stage 1 and Stage 2 was brought to the CAR laboratory facility and washed, air-dried, labeled, cataloged, analyzed, and curated. Artifacts were sorted, counted, and analyzed according to type including, lithic, ceramic, metal, and faunal remains. Lithic remains were divided and classified into primary, secondary, and tertiary flakes, edge modified flakes, bifaces, cores, and formal tools. All artifacts, field forms, notes, records, and photographs are curated in archival-quality containers, labeled, inventoried, and housed in CAR's permanent shelving.

\section{Results}

\section{Geomorphological Investigation of Quaternary Stratigraphy}

One Pleistocene and three Holocene alluvial units were identified in the project area. The Pleistocene unit appears to correlate with the early to middle Pleistocene Leona Formation. The Holocene units consist of an early Holocene terrace fill (Unit I), a late Holocene terrace fill (Unit II), and a modern floodplain fill (Unit III).

\section{Leona Formation}

Profile 1 in the project area was described from a quarry exposure near the ruins of Las Cabras (Figure 6). This profile exposed the oldest stratigraphic unit in the project area (Figure 9). It consisted of alternating beds of loams and sands grading into waterworn pebbles at a depth of $342 \mathrm{~cm}$ (Appendix A). Significant secondary carbonate accumulations occurred in multiple $\mathrm{Bk}$ and $\mathrm{Ck}$ horizons, the greatest accumulation in the $\mathrm{Bkm}$ horizon between a depth of 29 and $51 \mathrm{~cm}$. The Bkm horizon corresponds to Stage III carbonate accumulation according to the classification scheme of Gile et al. (1966). Machette (1985) shows that for climates similar to, but somewhat drier than the project area, Stage III carbonate accumulation indicates at least a late Pleistocene age, and perhaps a middle Pleistocene age.

Although mapped as the Weches Formation, unconsolidated fine-grained sediments and waterworn basal pebbles indicate that Profile 1 exposes an alluvial deposit. Based on descriptions from Barnes (1983), it seems that the deposit exposed by Profile 1 correlates with the early to middle Pleistocene Leona Formation. The Leona Formation appears to cover the western part of the project area, including the area around the Las Cabras ruins (Figure 6).

\section{Unit I}

In the project area, Unit I forms the first alluvial unit inset to the Leona Formation (Figure 6). Unit I can be traced up local gullies penetrating the uplands to the west. It may also be preserved as isolated remnants along the entire western valley escarpment.

Unit I was exposed in Profile 2 in a gully on the west side of the San Antonio River (Figure 6). In this locality, the unit was buried by a $27 \mathrm{~cm}$ veneer of recent sediments identified as Unit III (Figure 9). In Profile 2, Unit I consists of an A-Bw-Bk horizon sequence (Appendix A). Textures were sandy clay loam with a few matrix-supported and waterworn pebbles. Few to common filaments of secondary carbonate were present in the subsoil. The total 


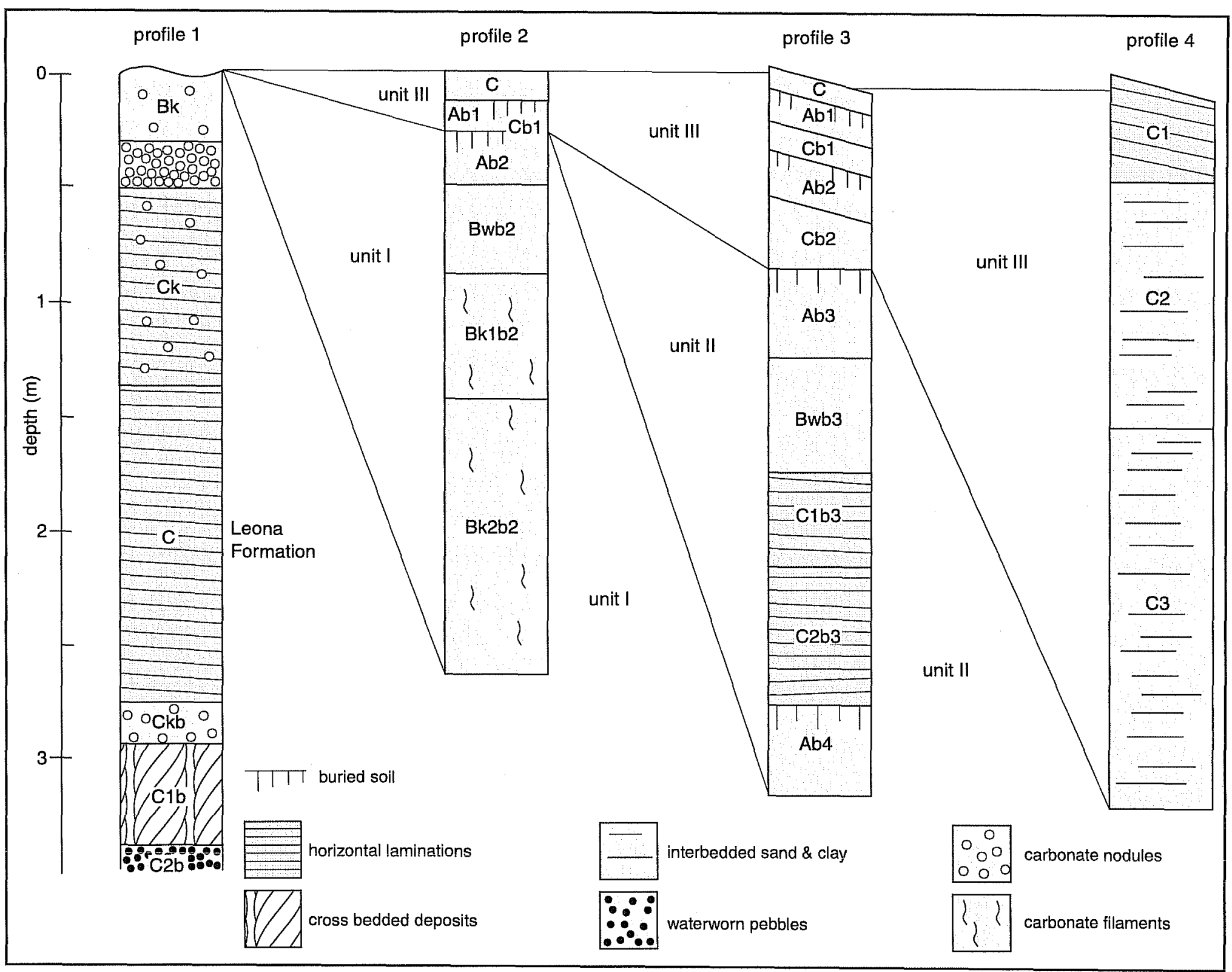

Figure 9. Soil stratigraphic columns from the project area. 
thickness of the Unit I alluvium is at least six meters thick.

Profile 2 was situated approximately $20 \mathrm{~m}$ above the low-water channel of the San Antonio River (Figure 6). Just to the south of the project area an extensive terrace occurs on the east side of the river valley at approximately the same elevation. This terrace was mapped as the Runge series (Argiustoll), which is a Mollisol with a clay increase and filaments of secondary carbonate in the subsoil (Taylor 1977). These properties were also observed for Unit I in the project area. Thus, based on elevation and degree of soil development, it appears that Unit I formed in an alluvial deposit that was preserved as a terrace just to the south of the project area where the San Antonio River valley widens.

Stratigraphic position and degree of soil development of Unit I is similar to an early to middle Holocene alluvial unit identified along Culebra Creek (Nordt 1997) and Leon Creek (Nordt 1996) in San Antonio. This is turn correlates with the Medina paleosol along the Medina River south of San Antonio (Thoms and Mandel 1992).

\section{Unit II}

In the project area, Unit II is stratigraphically inset to Unit I, 13-15 $\mathrm{m}$ above the low-water level of the San Antonio River. Unit II forms a flood terrace (tread and riser) within the large meander loop of the San Antonio River on the east side of the valley (Figure 6). It is also preserved as remnants bordering gullies penetrating the uplands along the western valley escarpment. In this area, Unit II is separated from Unit I by elevation and gully knickpoints.

Unit II was described in Profile 3 from a exposure along the western escarpment (Figure 6). Here Unit II was buried by at least $87 \mathrm{~cm}$ of Unit III sediments (Figure 9). The upper part of Unit II in Profile 3 was weathered to a loamy A-Bw-Chorizon sequence prior to burial (Appendix A). A buried A-horizon (Ab4) was identified at the bottom of the exposure in Unit II at a depth of $278 \mathrm{~cm}$. The $\mathrm{C}$ horizons within Profile 2 contained observable horizontal laminations. As with
Unit I, Unit II is at least six meters thick along the western valley escarpment. However, within $20 \mathrm{~m}$ upslope to the west-northwest of Profile 3, approximately one meter of Unit II sediments were unconformably burying Unit I. Thus, it appears that a narrow wedge of Unit $I I$ is inset to Unit I along the western valley escarpment. This area is mapped as an upland soil by Taylor (1977), probably because of the limited scale of mapping.

Unit II was also associated with the flood terrace within the large meander loop of the San Antonio River to the east. This area was mapped as the Aransas series, a fine-textured Haplaquoll (Taylor 1977). This taxonomic classification indicates the presence of a weakly developed and poorly drained Mollisol. Characteristics of a Mollisol are consistent with the soil properties observed in Profile 3 along the western valley escarpment.

Just to the south of the project area, an extensive flood terrace occurs within the within the meander belt of the San Antonio River at about the same elevation as Unit II within the project area. Downstream, this flood terrace is mapped mainly as the Karnes (Ustochrept, coarse-loamy) and Venus (Calciustoll, fine-loamy) soil series (Taylor 1977). A closer view of the descriptions of these soils reveals that their degree of development is virtually identical. Both have a few filaments of secondary carbonate with no clay increase with depth. The difference in classification is mainly because of texture; the Venus series is finer grained and thus darker (Mollisol) than the Karnes series (Inceptisol). The Karnes soils appear to be more common on the inside of sharp meander bends and where local tributaries enter the San Antonio River. In either case, elevation and soil development suggest that Unit II within the project area and the flood terrace just downstream are the same.

The stratigraphic position and degree of soil development of Unit II is similar to a late Holocene alluvial unit identified along Culebra Creek (Nordt 1997) and Leon Creek (Nordt 1996) in San Antonio. This is turn may correlate with the Leon Creek paleosol along the Medina River south of San Antonio (Thoms and Mandel 1992). 


\section{Unit III}

Unit III consists of modern floodplain deposits from Picosa Creek and the San Antonio River (Figure 6). It is inset to Unit II along the modern floodplains, the western escarpment, and up the western gully system. Within the modern meander bend of the San Antonio River to the east, Unit III occurs as a bench about eight meters above the low-water channel. In this general area, Unit III was described from Profile 4 at the confluence of Picosa Creek and the San Antonio River (Figure 9). Here Unit III consists of interbedded loams and clays reaching a thickness of $420 \mathrm{~cm}$ (Appendix A). The clayey interbedded component increases with depth, perhaps indicating greater depositional contributions from Picosa Creek in the past.

Unit III was also identified in Profiles 2 and 3 (Figure 6). In Profile 3, Unit III formed a multilayered flood deposit burying Unit II along the western escarpment, $15 \mathrm{~m}$ above the modern low-water channels of Picosa Creek and the San Antonio River (Figure 9). Here Unit III consists of at least $87 \mathrm{~cm}$ of interbedded loamy sediments and two weakly developed buried Ahorizons (Appendix A). This indicates high magnitude flood stages during the last 1,000 years, perhaps even during historic times. In Profile 2, near the contact between the Leona Formation and Unit I, Unit III consists of a loamy veneer burying Unit I (Figure 9). The Unit III veneer consists of a modern $\mathrm{C}$ horizon and a buried A-C profile sequence (Appendix A). Unit III in this area may have been derived from hillslope colluvium entering the gully from the Quarry area.

Minimal pedogenesis and the identification of a piece of plastic wrapping at a depth of $150 \mathrm{~cm}$ in Profile 4 demonstrate that at least part of Unit III is historic in age. Within the project area and just downstream, the weakly developed Loire (Ustifluvent) and Frio (Hapustoll) soil series are mapped, consistent with observations in Profile 4.

\section{Conclusions}

At least three-fourths of the Las Cabras NPS land appears to be covered with late Quaternary deposits inset to the Pleistocene Leona Formation (Figure 6). Accompanied by field observations, this demonstrates that prehistoric cultural material may be buried to depths of a few $\mathrm{cm}$ to as much as $20 \mathrm{~m}$ in this part of the project area. According to correlations with alluvial stratigraphies of other central Texas streams, Unit I may contain buried Paleoindian and Early Archaic sites. Unit II may have buried Middle Archaic to Late Prehistoric sites, whereas Unit III is at least historic in age. Prehistoric cultural material (a flake and a mussel shell) were collected at $230 \mathrm{~cm}$ bs in Profile 3 of Unit II. A small core was observed but not collected on the wall of a gully at the base of Unit I. Sites spanning the entire prehistory of Texas may be confined to the surface of the Leona Formation in the western part of the project area. However, no subsurface sites will be discovered in this area.

\section{Stage 1 Archaeological Investigations}

The project area covered by pedestrian survey and shovel testing during Stage 1 has been identified by the current geological investigation as the Early to Middle Pleistocene Leona Formation. Seven (STs 12, $16,27,29,30,31$, and 32) of the 32 shovel tests excavated during the Stage 1 investigation contained cultural material. Of these, six (STs 16, 27, 29, 30, 31 , and 32) were located fairly close to the west and north walls of the Rancho de las Cabras ruins (Figure 7). The soil within these shovel tests was a brown to pale brown, fine textured, sandy clay loam with calcium carbonate inclusions. Chert fragments comprised the largest percentage of artifacts found in this area. These were mainly small chert chunks, chips, and very small secondary and tertiary flakes (Table 1). No cultural material was recovered below $40 \mathrm{~cm}$ bs. ST 29, Level $2(10-20 \mathrm{~cm})$ contained one unglazed red-paste ceramic body fragment, measuring $0.8 \times 0.6$ $\mathrm{mm}$ in size. This was found in association with two secondary flakes and one chert chip. Seven artifacts were recovered from ST 29, representing the largest quantity found in all the shovel tests excavated. Within ST 30 , Level $4(30-40 \mathrm{~cm})$ one unidentifiable mammaliam faunal fragment was recovered with one secondary flake. ST 31 contained faunal remains in Level $1(0-10 \mathrm{~cm})$. These included one fragment of a medial diaphysis of a deer-sized artiodactyl, two 
Table 1. Artifacts Recovered during Stage 1 Shovel Testing

\begin{tabular}{|c|c|c|c|c|c|}
\hline ST \# & $\begin{array}{c}\text { Level } 1 \\
(0-10 \mathrm{~cm})\end{array}$ & $\begin{array}{c}\text { Level } 2 \\
(10-20 \mathrm{~cm})\end{array}$ & $\begin{array}{c}\text { Level } 3 \\
(20-30 \mathrm{~cm})\end{array}$ & $\begin{array}{c}\text { Level } 4 \\
(30-40 \mathrm{~cm})\end{array}$ & $\begin{array}{c}\text { Level } 5 \\
(40-50 \mathrm{~cm})\end{array}$ \\
\hline 12 & $\begin{array}{l}1 \text { chert chip } \\
\text { (poss. heat } \\
\text { modified) }\end{array}$ & & & & \\
\hline 16 & 1 chert chunk & $\begin{array}{l}1 \text { chert chunk, } \\
1 \text { secondary flake }\end{array}$ & & & \\
\hline 27 & & & & 3 secondary flakes & \\
\hline 29 & & $\begin{array}{l}2 \text { secondary flakes, } \\
1 \text { chert chip, } \\
1 \text { unglazed ceramic } \\
\text { sherd }\end{array}$ & 2 tertiary flakes & 1 tertiary flake & \\
\hline 30 & & 1 tertiary flake & & $\begin{array}{l}1 \text { secondary flake, } \\
1 \text { unidentifiable } \\
\text { faunal fragment }\end{array}$ & \\
\hline 31 & $\begin{array}{l}4 \text { faunal fragments } \\
\text { ( } 1 \text { de er, } 2 \text { turtle, } \\
1 \text { unidentifiable) }\end{array}$ & & & & \\
\hline 32 & & 1 tertiary flake & & & \\
\hline
\end{tabular}

fragments of Pseudomys sp. (pond slider turtle), and one unidentifiable burned bone fragment.

ST 12 contained one very small, possibly heatmodified chert chip within Level $1(0-10 \mathrm{~cm})$. ST 12 (Stage 1 shovel testing) is located within the site boundary of 41WN90, identified and mapped during Stage 2 archaeological survey and testing.

Table 2 was generated to show the soil color variations discernible over the Stage 1 archeological shovel testing project area. Within the Stage 1 area, two distinct patterns are evident in the soils recorded during shovel testing. In STs $20,21,23,24$, and 25 very dark grayish-brown to dark brown (10YR $3 / 2$ to $3 / 3$ ) sandy clay loam soils were recorded (Figure 10). In the remaining shovel tests, yellowish-brown to brown soils are recorded. Also in the first set of shovel tests the dark soils occur to depths of $50 \mathrm{~cm}$ or more. Clearly these represent an accumulation of organic materials and qualifies these soils as over-thickened A-horizons. Nowhere in the Stage 2 Area are such dark soils recorded. The dark soils are adjacent to the Las Cabras ruins and it is possible that these over-thickened Ahorizons formed from anthropogenic activities associated with the Colonial ranching activities. This anomaly could represent an external corral or a dump area. Topographic maps show that the dark overthickened A-horizon occurs at a topographic high point. It is possible that these thicker soils had a broader distribution, but that they have been truncated by slope erosion, especially on the southern side which slopes down to an intermittent drainage at the southern property boundary.

As is true of the Las Cabras ruins, the over-thickened A-horizon is located on the Pleistocene Leona Formation. This formation is illustrated in Profile 1 (Figure 9). Cultural material from any time period may be recovered on the Leona Formation. This part of the project area does not have the potential for containing intact, cultural material buried by natural geomorphological processes; however, the possibility exists that artifacts or features may have been either directly or indirectly buried by humans. 
Table 2. Soil Colors from Stage 1 Shovel Tests

\begin{tabular}{|c|c|}
\hline $\mathbf{S T} \#$ & Soil Color \\
\hline 1 & dark yellowish brown \\
\hline 2 & dark yellowish brown \\
\hline 3 & yellowish brown \\
\hline 4 & Mottled yellowish brown and dark yellowish brown \\
\hline 5 & brown \\
\hline 6 & Mottled gray, yellowish brown and brown \\
\hline 7 & yellowish gray \\
\hline 8 & light yellowish brown \\
\hline 9 & light yellowish brown \\
\hline 10 & dark yellowish brown \\
\hline 11 & brown \\
\hline 12 & very pale brown \\
\hline 13 & light yellowish brown \\
\hline 14 & brown \\
\hline 15 & dark yellowish brown \\
\hline 16 & brown \\
\hline 17 & brown \\
\hline 18 & very pale brown \\
\hline 19 & brown \\
\hline 20 & very dark grayish brown \\
\hline 21 & dark brown \\
\hline 22 & dark yellowish brown \\
\hline 23 & very dark grayish brown \\
\hline 24 & very dark grayish brown \\
\hline 25 & dark brown \\
\hline 26 & dark yellowish brown \\
\hline 27 & brown \\
\hline 28 & dark yellowish brown \\
\hline 29 & yellowish brown \\
\hline 30 & gray ish brown \\
\hline 31 & dark yellowish brown \\
\hline 32 & gray ish brown \\
\hline
\end{tabular}

\section{Newly Recorded Sites}

\section{WN90}

Site 41WN90 is located in the southeastern area of the southern tract (private property) and the southwestern area of the Stage 1 investigation (NPS property; Figure 7). It is approximately $120 \mathrm{~m}$ north/south by $60 \mathrm{~m}$ east/west in size. The site ranges in elevation from 410 to $420 \mathrm{ft}$ above mean sea level (amsl). Characterized by a light density of surface lithic material, 41WN90 consists of primary, secondary, and tertiary flakes; three cores; a possible Guadalupe tool; a biface fragment; and plow-damaged chert. Eleven shovel tests (STs 1-8, 39 and 40 from Stage 2, and ST 12 from Stage 1), excavated to a depth of $50 \mathrm{~cm}$ bs, demonstrate that the site is largely restricted to the surface.

Only four of the 11 shovel tests (STs 1, 3, 4, and 12 from Stage 1) contained cultural material (Tables 1 and 3). Present in ST 1 was a secondary flake in Level 1, and a secondary and tertiary 


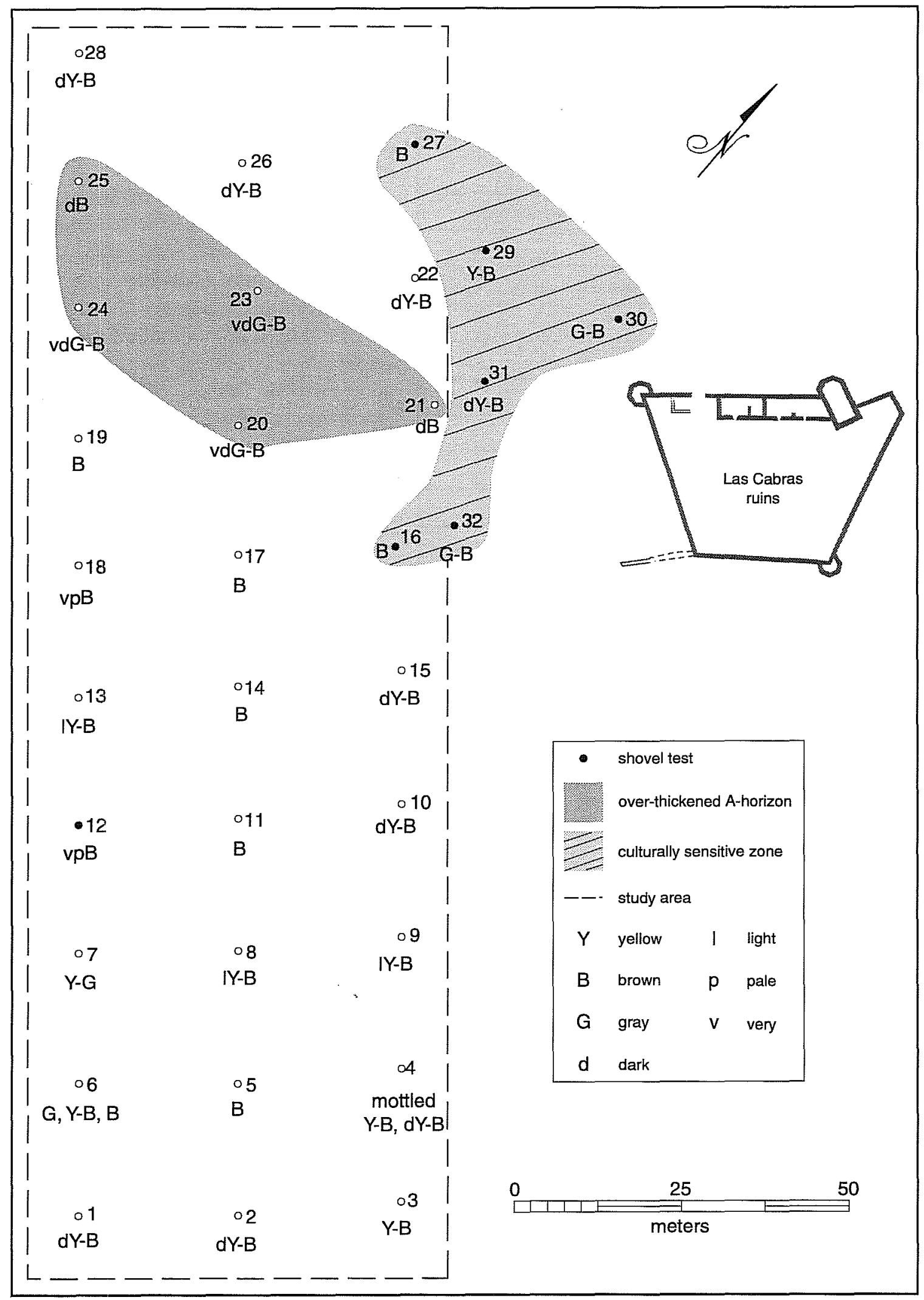

Figure 10. Soil color map for Stage 1. 
Table 3. Artifacts Recovered during Stage 2 Shovel Testing

\begin{tabular}{|c|c|c|c|c|c|}
\hline ST \# & $\begin{array}{c}\text { Level } 1 \\
(0-10 \mathrm{~cm})\end{array}$ & $\begin{array}{c}\text { Level } 2 \\
(10-20 \mathrm{~cm})\end{array}$ & $\begin{array}{c}\text { Level } 3 \\
(20-30 \mathrm{~cm})\end{array}$ & $\begin{array}{c}\text { Level } 4 \\
(30-40 \mathrm{~cm})\end{array}$ & $\begin{array}{c}\text { Levell } 5 \\
(40-50 \mathrm{~cm})\end{array}$ \\
\hline 1 & 1 secondary flake & & & & $\begin{array}{l}1 \text { secondary flake, } \\
1 \text { tertiary flake }\end{array}$ \\
\hline 3 & 1 tertiary flake & & & 2 secondary flakes & 3 secondary flakes \\
\hline 4 & 1 primary flake & & & & \\
\hline 25 & & & & 1 secondary flake & \\
\hline 35 & & 1 secondary flake & & & \\
\hline 56 & 1 tertiary flake & & & & \\
\hline 66 & & 1 tertiary flake & & & \\
\hline 69 & 1 tertiary flake & & & & \\
\hline 70 & & 1 secondary flake & & & \\
\hline 73 & $\begin{array}{l}1 \text { primary flake, } \\
1 \text { secondary flake }\end{array}$ & & & & \\
\hline 74 & & & 1 secondary flake & & \\
\hline 80 & & 1 primary flake & & & \\
\hline 90 & . & & $\begin{array}{l}1 \text { primary flake, } \\
1 \text { tertiary flake }\end{array}$ & & \\
\hline 91 & & & & & core \\
\hline
\end{tabular}

flake in Level 5. ST 3 contained a tertiary flake in Level 1, three secondary flakes in Level 3, and two secondary flakes in Level 4. Present in ST 4 was one primary flake in Level 1. ST 12 (Stage 1) contained one chert chip in Level 1. STs 1 and 3-which contained lithics in Level 5 and Levels 4 and 5 respectively-are separated by $60 \mathrm{~m}$. ST 2 is located between STs 1 and 3 and contained no cultural material. Furthermore, cultural material was not observed in STs 39 or 40 , which are located near STs 1 and 3 (Figure 7). The cultural material observed below the surface may be due to previous subsurface disturbance. Winston Southern (1997 personal communication) reports that deep root cutting and plowing in the site area probably disturbed approximately 30 to $45 \mathrm{~cm}$ of subsurface soil. Characterization units placed across the site show the sparseness of cultural material located on the surface (Figure 7). Each of the characterization units was $3 \times 3 \mathrm{~m}$ in size (Table 4). Sixty-six artifacts were collected in a $396-$ $\mathrm{m}^{2}$ area, for an artifact density of $.17 / \mathrm{m}^{2}$ (Table 5). The lack of diagnostic artifacts (with the exception of the possible Guadalupe tool) precludes assigning this site to any cultural time period. The lithic material may represent either a prehistoric component (Early Archaic?), or possibly a historic component related to the life of Native American occupants of Rancho de las Cabras. It is quite possible that it represents a combination of the two. Today, the majority of the site is impacted by cattle grazing, while the northeastern part of the site lies within the NPS unit of Rancho de las Cabras.

\section{WN91}

Site $41 \mathrm{WN} 91$ is located in the northern section of the southern tract (Figure 7). It is approximately $90 \mathrm{~m}$ north/south by $210 \mathrm{~m}$ east/west in size. The topography of the site area is basically level with an elevational 
Table 4. Artifacts Recovered from Characterization Units and Special Collections at 41WN90

\begin{tabular}{|c|l|}
\hline Unit & \multicolumn{2}{|c|}{ Recovered Artifacts } \\
\hline Characterization Units $(\mathbf{3} \mathbf{x} \mathbf{3} \mathbf{~} \mathbf{)}$ \\
\hline A & core \\
\hline B & 1 tertiary flake \\
\hline C & 1 secondary flake \\
\hline D & 2 secondary flakes, core \\
\hline E & none \\
\hline F & tested cobble, primary flake \\
\hline G & none \\
\hline H & none \\
\hline I & none \\
\hline J & none \\
\hline K & 1 secondary flake \\
\hline L & 1 chert chunk \\
\hline M & none \\
\hline N & 1 secondary flake \\
\hline O & 2 tertiary flakes \\
\hline P & $\begin{array}{l}3 \text { secondary flakes, } 2 \text { rimless Center Fire } 32 \text { caliber } \\
\text { bottleneck shells }\end{array}$ \\
\hline Q & $\begin{array}{l}\text { 1 ed ge-modified flake, } 4 \text { secondary flakes, } 1 \text { core, } 1 \\
\text { rimless center fire .32 caliber bottleneck shell }\end{array}$ \\
\hline R & none \\
\hline S & none \\
\hline T & 1 tertiary flake \\
\hline U & 1 secondary flake \\
\hline V & none \\
\hline W & 3 secondary flakes \\
\hline X & none \\
\hline Z & none \\
\hline & none \\
\hline
\end{tabular}

\begin{tabular}{|c|l|}
\hline Unit & \multicolumn{2}{|c|}{ Recovered Artifacts } \\
\hline Characterization Units $(\mathbf{3} \times \mathbf{3}$ m) \\
\hline AA & none \\
\hline B B & none \\
\hline CC & none \\
\hline DD & 2 secondary flakes \\
\hline EE & 3 secondary flakes \\
\hline FF & 2 secondary flakes \\
\hline GG & 1 primary flake, 4 secondary flakes \\
\hline HH & 2 primary flakes, 2 secondary flakes, 1 tertiary flake \\
\hline II & 1 primary flake \\
\hline JJ & none \\
\hline KK & none \\
\hline LL & 1 secondary flake \\
\hline MM & 1 primary flake \\
\hline NN & 1 secondary flake \\
\hline OO & 2 secondary flakes \\
\hline PP & 2 primary flakes, 4 secondary flakes, 1 tertiary flake \\
\hline QQ & 6 secondary flakes \\
\hline RR & 2 secondary flakes, core fragment \\
\hline Special Collections, Surface Artifacts \\
\hline 1 & secondary flake, quartzite \\
\hline 2 & secondary flake, quartzite \\
\hline 3 & core \\
\hline 4 & possible guadalupe tool \\
\hline 5 & biface fragment \\
\hline
\end{tabular}

Table 5. Total Characterization Area Collected and Artifact Density for 41WN90, 41WN91, and 41WN93

\begin{tabular}{|l|c|c|c|}
\cline { 2 - 4 } \multicolumn{1}{c|}{} & $\mathbf{4 1}$ WN90 & 41 WN91 & 41 WN93 \\
\hline Total $\mathrm{m}^{2}$ collected & 396 & 25 & 81 \\
\hline Total artifacts collected & 66 & 9 & 6 \\
\hline Artifact Density (artifacts $\left./ \mathrm{m}^{2}\right)$ & 0.17 & 0.36 & 0.07 \\
\hline
\end{tabular}

difference of only one foot $(420-421 \mathrm{ft}$ amsl). The site is characterized by a light density of cultural material, broadly distributed, with three areas of concentration (Figure 7). Lithic artifacts observed on the surface include primary, secondary and tertiary flakes; an edge-modified flake; early- and middlestage bifaces, two lead-glazed ceramic sherds (postdating the 1900s); and plow-damaged chert.
Twenty shovel tests (STs 41-59), excavated to a depth of $50 \mathrm{~cm}$, demonstrate that the site is restricted to the surface (Figure 7). Only two of the 20 shovel tests (STs 41 and 56) yielded artifacts below the surface (Table 3). In ST 41, a core was recovered between 40 and $50 \mathrm{~cm}$ bs. In ST 56 one tertiary flake was observed in Level 1 (0-20 cm bs). Winston Southern (personal communication 1997) reports that plowing has 
disturbed approximately $7-8$ inches $(20 \mathrm{~cm})$ of the subsurface. Recovered materials from characterization units indicate a low density of artifacts for the site. Each of the characterization units was $1 \times 1 \mathrm{~m}$ in size (Table 6 and Figure 7). Nine artifacts were collected in a $25-\mathrm{m}^{2}$ area, for an artifact density of $.36 / \mathrm{m}^{2}$ (Table 5). It is unknown, due to the absence of diagnostic material, whether the site represents prehistoric occupation of the area or historic use by Native American occupants of Rancho de las Cabras. It is possible that it represents a combination of the two. Today, site 41WN91 is located within a cultivated field and is impacted by agricultural activities.

Table 6. Artifacts Recovered from Characterization Units and Special Collections at 41WN91

\begin{tabular}{|c|l|}
\hline Unit & \multicolumn{2}{|c|}{ Recovered Artifacts } \\
\hline Characterization Units (1 $x$ 1 $\mathbf{m})$ \\
\hline A & 1 secondary flake \\
\hline B & none \\
\hline C & 1 secondary flake and 1 tertiary flake \\
\hline D & none \\
\hline E & none \\
\hline F & 1 secondary flake \\
\hline G & 1 primary flake \\
\hline H & 1 secondary flake \\
\hline I & none \\
\hline J & none \\
\hline K & 1 edge-modified flake and 1 biface fragment \\
\hline L & none \\
\hline M & none \\
\hline N & none \\
\hline O & none \\
\hline P & none \\
\hline Q & none \\
\hline R & none \\
\hline S & none \\
\hline T & none \\
\hline U & none \\
\hline V & none \\
\hline W & none \\
\hline X & 1 secondary flake \\
\hline Y & none \\
\hline Special Collections, Surface Artifacts \\
\hline 1 & lead-glazed ceramic sherd, post-1900 \\
\hline 2 & middle-stage biface \\
\hline 3 & early-stage biface \\
\hline 4 & lead-glazed ceramic sherd, post-1900 \\
\hline
\end{tabular}

\section{WN92}

Site $41 \mathrm{WN} 92$ is located at the western end of the Access Road (Figure 8). It measures approximately $90 \mathrm{~m}$ east/west by $25 \mathrm{~m}$ north/south in size. Site elevation ranges between 410 and $420 \mathrm{ft}$ amsl. Characterized by a light, broad distribution of surface lithic artifacts, 41WN92 includes primary, secondary, and tertiary flakes; two cores; a biface; and plowdamaged chert. Three shovel tests (STs 64-66), dug to a depth of $50 \mathrm{~cm}$, demonstrate that the site is largely restricted to the surface (Table 3). One shovel test (ST 66) yielded a tertiary flake in Level $2(10-20 \mathrm{~cm} \mathrm{bs})$. Given the numerous examples of plow-damaged chert, cultural material observed to a depth of approximately $20 \mathrm{~cm}$ is likely to be disturbed. The lack of diagnostic artifacts precludes assigning this site to any prehistoric cultural period. Today, the site is located within the NPS's unimproved access road.

\section{WN93}

Site 41WN93 is located near the western end of the access road approximately $70 \mathrm{~m}$ east of $41 \mathrm{WN} 93$ (Figure 8). It is approximately $70 \mathrm{~m}$ east/west by $25 \mathrm{~m}$ north/south in size. The site ranges in elevation from 410 to $415 \mathrm{ft}$ amsl. Characterized by a light density of surface lithic artifacts, 41WN93 includes primary, secondary, and tertiary flakes; two edge-modified flakes; a biface; and plow-damaged chert. Three shovel tests (STs 70-72), dug to a depth of $50 \mathrm{~cm}$, demonstrate that the site is largely restricted to the surface. ST 70 only yielded one secondary flake, in Level 2 (10-20 cm bs) (Table 3). Given the numerous examples of plow-damaged chert, cultural material observed to a depth of approximately $20 \mathrm{~cm}$ is likely to be disturbed. Characterization units placed across the site show the sparseness of cultural material located on the surface. Each characterization unit was $3 \times 3 \mathrm{~m}$ in size (Table 7). Six artifacts were collected in an $81-\mathrm{m}^{2}$ area, for an artifact density of $.07 / \mathrm{m}^{2}$ (Table 5). The lack of diagnostic artifacts precludes assigning this site to any 
Table 7. Artifacts Recovered from Characterization Units and Special Collections at 41WN93

\begin{tabular}{|c|l|}
\hline Unit & \multicolumn{2}{|c|}{ Recovered Artifacts } \\
\hline Characterization Units $(3 \times \mathbf{~} \mathbf{~})$ \\
\hline A & none \\
\hline B & none \\
\hline C & none \\
\hline D & second ary flake \\
\hline E & none \\
\hline F & none \\
\hline G & 1 secondary flake and 1 primary flake \\
\hline H & none \\
\hline I & 2 edge-modified flakes and 1 secondary flake \\
\hline
\end{tabular}

prehistoric cultural period. Today, the site is located within the NPS's unimproved access road.

\section{Summary and Recommendations}

A two-stage investigation for cultural resources was conducted within the project boundary. This included pedestrian survey, shovel testing, and a preliminary geomorphological assessment.

In the upland Early to Middle Pleistocene Leona Formation, four newly identified prehistoric sites were recorded and mapped. All four sites are characterized by a light density of lithic cultural material and can be defined as surface lithic scatters. A paucity of subsurface cultural material was recovered during shovel testing, and previous subsurface disturbance in the form of deep root cutting and plowing is substantial. The research potential of these broad, sparse, lithic scatter sites is therefore considered minimal.

Sites 41WN90, 41WN92, and 41WN93 are located on NPS property and are thus included in the 1977 National Register nomination. The systematic collection of surface artifacts conducted during the current investigation has, in effect, mitigated these sites by exhausting their research potential. Site 41 WN91, currently located on private property, is not recommended as eligible for inclusion in the National Register of Historic Places. Therefore, no additional archaeological investigation is recommended prior to construction in the area of these four sites.

The archaeological investigations during Stage 1 included six shovel tests, near the western edge of the ruins, containing artifacts associated with the occupation of the ranch (Figures 7 and 10). Cultural material -lithic flakes, an unglazed ceramic sherd, and faunal remains (Table 1) - indicate that this area is archaeologically sensitive and further work is recommended prior to any ground-disturbing activities. In addition, an area of isolated dark soil (over-thickened Ahorizon) located west of the ruins may have formed from activities associated with the Colonial ranch (Figures 7 and 10). The area may have served as an external corral or dump; therefore, this area is also recommended for further testing prior to any grounddisturbing activities.

The geomorphological investigations of Rancho de las Cabras National are preliminary, and are intended to aid the NPS in future plans related to park development. Geoarchaeological conclusions suggest a widespread potential for finding buried prehistoric sites. Thus, more fieldwork is needed to test the model of landscape evolution and site distribution proposed in this report. The current model was based on one day of fieldwork, which included observing limited 
channel and gully cutbank exposures. The following list of activities is suggested for future geoarchaeological work in the project area.

1. Field reconnaissance of additional gullies and channel cutbanks is necessary to verify or reject the preliminary stratigraphic model and to find additional exposures for descriptions and sampling.

2. Backhoe trenches are needed in the Leona Formation and each of the three Holocene alluvial units to provide exposures for detailed soil stratigraphic descriptions, to establish crucial stratigraphic contacts, and for collection of carbon-fourteen $\left({ }^{14} \mathrm{C}\right)$ samples.

3. ${ }^{14} \mathrm{C}$ determinations are needed from the bottoms and tops of the early Holocene (Unit I) and late Holocene (Unit II) terraces to determine the potential for finding buried prehistoric sites, and to infer the potential ages of discovered archaeological sites.

4. Laboratory analyses from soil-stratigraphic samples is important for establishing baseline sedimentological information, for stratigraphic correlation, and for estimating soil age.

Clearance is recommended for the NPS to commence with construction of a parking lot and visitors' center only within the project area covered by the 1997 archaeological pedestrian survey and shovel testing, provided the areas west of the ruins identified as an over-thickened A-horizon and a culturally sensitive zone (Figures 7 and 10) are avoided. Future construction plans in the areas of the over-thickened Ahorizon, the culturally sensitive zone, the alluvial terraces, or any other area not tested during the 1997 investigation would require additional testing under a separate Texas Antiquities Permit. 


\section{References Cited}

Bannon, J. F.

1979 The Spanish Borderlands Frontier 1513-1821. University of New Mexico Press, Albuquerque.

Barnes, V. E.

1983 Geologic Atlas of Texas. San Antonio Sheet. Bureau of Economic Geology, The University of Texas at Austin.

Black, S. L.

1989a Environmental Setting. In From the Gulf Coast to the Rio Grande: Human Adaptation in the Central, South, and Lower Pecos Texas, edited by T. R. Hester, S. L. Black, D. G. Steele, B. W. Olive, A. A. Fox, K. J. Reinhard, and L. C. Bemet, pp. 5-17. Research Series No. 33. Arkansas Archaeological Survey, Fayetteville.

1989b South Texas Plain. In From the Gulf Coast to the Rio Grande: Human Adaptation in the Central, South, and Lower Pecos Texas, edited by T. R. Hester, S. L. Black, D. G. Steele, B. W. Olive, A. A. Fox, K. J. Reinhard, and L. C. Bement, pp. 39-62. Research Series No. 33. Arkansas Archaeological Survey, Fayetteville.

Blair, W. F.

1950 The Biotic Provinces of Texas. The Texas Journal of Science 2(1):93-117.

Bruseth, J. E.

1992 Artifacts of the De Soto Expedition: The Evidence from Texas. Bulletin of the Texas Archeological Society 63:67-97.

Collins, M. B.

1995 Forty Years of Archaeology in Texas. Bulletin of the Texas Archeological Society 66:361-400.

Collins, M. B., and R. A. Ricklis

1994 Cultural Background. In Archaic and Late Prehistoric Human Ecology in the Middle Onion Creek Valley, Hays County, Texas, edited by M. B. Collins and R. A. Ricklis, 1:11-26. Studies in Archeology 19. Texas Archeological Research Laboratory, The University of Texas at Austin.

Folk, R. L.

1980 Petrology of Sedimentary Rocks. Hemphill, Austin.

Fox, A. A.

1998 Archaeological and Historical Investigations at Rancho De Las Cabras, 41WN30, Wilson County Texas, Fourth Season. Archaeological Survey Report, No. 143. Center for Archaeological Research, The University of Texas at San Antonio.

Gile, L. H., F. F. Peterson, and R. B. G. Grossman

1966 Morphology and Genetic Sequences of Carbonate Accumulation in Desert Soils. Soil Science 101: 347-360. 
Hard, R. J., M. Renner, and A. J. Taylor

1996 Methodology. In Archaeological Survey of Laughlin Air Force Base, Val Verde County, Texas, edited by C. Tennis, M. Renner and R. J. Hard, pp. 20-27. Archaeological Survey Report No. 239. Center for Archaeological Research, The University of Texas at San Antonio.

Hester, T. R.

1975 Late Prehistoric Cultural Patterns Along the Lower Rio Grande of Texas. Texas Archeological Society 46:105-125.

1981 Tradition and Diversity Among the Prehistoric Hunters and Gatherers of Southern Texas. Plains Anthropologist 26(92):119-128.

1995 The Prehistory of South Texas. Bulletin of the Texas Archeological Society 66:427-459.

Ivey, J. E.

1983 Archaeological Testing at Rancho De Las Cabras, 41WN30, Wilson County, Texas Second Season. Archaeological Survey Report, No. 121. Center for Archaeological Research, The University of Texas at San Antonio.

1984 The San Antonio Missions. Manuscript on file, Center for Archaeological Research, The University of Texas at San Antonio.

1991 Mission Land Use in the San Antonio River Valley. Manuscript on file, Center for Archaeological Research, The University of Texas at San Antonio.

Ivey, J. E., and A. A. Fox

1981 Archaeological Survey and Testing at Rancho de las Cabras, Wilson County, Texas. Archaeological Survey Report, No. 104. Center for Archaeological Research, The University of Texas at San Antonio.

Jones, C. J., and A. A. Fox

1983 Archaeological Testing at Rancho De Las Cabras, Wilson County, Texas, Third Season. Archaeological Survey Report, No. 123. Center for Archaeological Research, The University of Texas at San Antonio.

Labadie, J. H.

1988 Archaeological Excavations at the Shrew Site 41 WN73 Wilson County, Southern Texas. Contract Reports in Archaeology, Report No. 2. Texas State Department of Highways and Public Transportation, Austin.

Machette, M. N.

1985 Calcic Soils of the Southwestern United States. In Soils and Quaternary Geology of the Southwestern United States, edited by D. L. Weide, pp 1-21. Special Paper 203. Geological Society of America, Boulder, Colorado.

McClure, W.

1983 Provenience of Faunal Material. In Archaeological Testing at Rancho De Las Cabras, Wilson County, Texas, Third Season, by A. A. Fox, pp. 54-68. Archaeological Survey Report, No 123. Center for Archaeological Research, The University of Texas at San Antonio. 
Nordt, L. C.

1996 Geoarchaeology of 41BX47, Upper Leon Creek Basin. In Archaic Land Use of Upper Leon Creek Terraces: Archaeological Testing in Northern Bexar County, Texas, by C. L. Tennis, pp. 1-19. Archaeological Survey Report, No. 234. Center for Archaeological Research, The University of Texas at San Antonio.

1997 Geoarchaeology of Site 41BX126 Along Culebra Creek in Bexar County, Texas. Manuscript on file, Center for Archaeological Research, The University of Texas at San Antonio.

Sanchez, J. P.

1992 From El Paso to Eagle Pass: Spanish Entradas Along the Lower Rio Grande in the Sixteenth and Seventeenth Centuries. Bulletin of the Texas Archeological Society 63:53-66.

Scott, R. F., IV, and D. E. Fox

1982 Excavations at Sites 41LK31/32 and 41LK202 in the Choke Canyon Reservoir, South Texas. Choke Canyon Series 8. Center for Archaeological Research, The University of Texas at San Antonio.

Soil Survey Division

1993 Soil Survey Manual. U.S. Department of Agriculture Handbook No. 18. U.S. Government Printing Office, Washington, D.C.

Steele, G. D., and G. B. DeMarcay

1985 Analysis of Faunal Remains Recovered During the 1984 Excavations at Rancho De Las Cabras. In Archaeological Survey and Testing at Rancho De Las Cabras, 4IWN30, Wilson County, Texas, Fifth Season. Archaeological Survey Report, No. 144. Center for Archaeological Research, The University of Texas at San Antonio.

1986 Analysis of Vertebrate Faunal Remains from 41MC222 and 41MC296, McMullen County, Texas. In The Prehistoric Sites at Choke Canyon Reservoir, Southern Texas: Results of Phase II Archaeological Investigations, by G. D. Hall, T. R. Hester, and S. L. Black, pp. 452-502. Choke Canyon Series 10. Center for Archaeological Research, The University of Texas at San Antonio.

Steele, D. G., and C. Assad Hunter

1986 Analysis of Vertebrate Faunal Remains from 41MC222 and 41MC296, McMullen County, Texas. In The Prehistoric Sites at Choke Canyon Reservoir, Southern Texas: Results of Phase II Archaeological Investigations, by G. D. Hall, T. R. Hester, and S. L. Black, pp. 452-502. Choke Canyon Series 10. Center for Archaeological Research, The University of Texas at San Antonio.

Taylor, A. J., and A. A. Fox

1985 Archaeological Survey and Testing at Rancho De Las Cabras, 41WN30, Wilson County, Texas, Fifth Season. Archaeological Survey Report, No. 144. Center for Archaeological Research, The University of Texas at San Antonio.

Taylor, F. B.

1977 Soil Survey of Wilson County, Texas. U.S. Department of Agriculture, Soil Conservation Service. U.S. Government Printing Office, Washington, D.C.

Thoms, A. V., and R. D. Mandel

1992 The Richard Beene Site: A Deeply Stratified Paleoindian to Late Prehistoric Occupation in SouthCentral Texas. Current Research in the Pleistocene 9:43-44. 


\section{Appendix A: Soil Stratigraphic Descriptions}

\section{Profile 1: Leona Formation; Quarry; $415 \mathrm{ft}$ elevation; calcareous throughout.}

$\begin{array}{ll}\mathrm{Bk} & 0-29 \mathrm{~cm} \\ \mathrm{Bkm} & 29-51 \mathrm{~cm} \\ \mathrm{Ck} & 51-136 \mathrm{~cm} \\ \mathrm{C} & 136-277 \mathrm{~cm} \\ \mathrm{Ckb} & 277-292 \mathrm{~cm} \\ \mathrm{C} 1 \mathrm{~b} & 292-342 \mathrm{~cm} \\ \mathrm{C} 2 \mathrm{~b} & 342+\mathrm{cm}\end{array}$

light yellowish brown (10YR 6/4) sandy clay loam; weak coarse prismatic; hard; $2 \%$ carbonate nodules, $1 \mathrm{~cm}$ diameter, soft; many biocasts; abrupt wavy. $70 \%$ coalescing carbonate nodules (Stage III); few distinct yellowish brown iron stains; many biocasts; abrupt wavy. white (10YR 8/1) loam; common distinct brownish yellow (10YR 6/6) iron stains; $2 \%$ carbonate nodules, $1 \mathrm{~cm}$ diameter, soft; many biocasts; faint horizontal laminations; hard; abrupt wavy.

white (10YR 8/1) fine sand; common distinct brownish yellow (10YR 6/6) iron stains; many biocasts; faint horizontal laminations; slightly hard; abrupt wavy. yellowish brown (10YR 5/6) sandy clay loam; 30\% white (10YR 8/1); massive; very hard; $10 \%$ carbonate nodules, $1 \mathrm{~cm}$ diameter, soft; abrupt wavy. white (10YR 8/1) fine sand; 30\% yellow (10YR 7/6) iron stains; distinct laminar cross beds; slightly hard; abrupt wavy.

iron stone and siliceous pebbles, 0.5 to $5 \mathrm{~cm}$ diameter, subrounded, moderately well sorted, grain supported; partially cemented.

\section{Profile 2: Alluvial terrace inset to Leona Formation along gully; $400 \mathrm{ft}$ elevation; calcareous throughout.}

C $\quad 0-15 \mathrm{~cm}$

$\mathrm{Ab} 1 \quad 15-22 \mathrm{~cm}$

$\mathrm{Cb} 1 \quad 22-27 \mathrm{~cm}$

Ab2 $\quad 27-51 \mathrm{~cm}$

Bwb2 $\quad 51-90 \mathrm{~cm}$

Bk1b2 90-144 cm

$\mathrm{Bk} 2 \mathrm{~b} 2 \quad 144-262 \mathrm{~cm}$

$262-610 \mathrm{~cm}$
Unit III; yellowish brown (10YR 5/4) sandy clay loam; moderate medium subangular blocky; hard; $5 \%$ pebbles, 1 to $3 \mathrm{~cm}$ diameter, subrounded, matrix supported; abrupt smooth.

very dark grayish brown (10YR 3/2) fine sandy loam; moderate coarse subangular blocky; hard; gradual smooth.

dark grayish brown (10YR 4/2) fine sandy loam; moderate coarse subangular blocky; hard; abrupt smooth.

Unit I; very dark brown (10YR 2/2) sandy clay loam; weak coarse subangular blocky; hard; $2 \%$ pebbles, 0.5 to $2 \mathrm{~cm}$ diameter, subrounded, matrix supported; gradual smooth.

very dark grayish brown (10YR 3/2) sandy clay loam; weak coarse subangular blocky; hard; $2 \%$ pebbles, 0.5 to $2 \mathrm{~cm}$ diameter, subrounded, matrix supported; gradual smooth.

brown (10YR 4/3) sandy clay loam; weak coarse prismatic; very hard; $3 \%$ carbonate filaments; $2 \%$ pebbles, 0.5 to $2 \mathrm{~cm}$ diameter, subrounded, matrix supported; gradual smooth.

dark yellowish brown (10YR 4/4) sandy clay loam; weak coarse prismatic; very hard; $6 \%$ carbonate filaments; $3 \%$ pebbles, 0.5 to $2 \mathrm{~cm}$ diameter, subrounded, matrix supported; gradual smooth.

measured to bottom of gully. 


\section{Profile 3: Alluvial terrace inset to Unit I along gully; $365 \mathrm{ft}$ elevation; one meter of Unit III alluvium above profile, but not described; calcareous throughout.}

$\begin{array}{ll}\mathrm{C} & 0-9 \mathrm{~cm} \\ \mathrm{Ab} 1 & 9-23 \mathrm{~cm} \\ \mathrm{Cb} 1 & 23-33 \mathrm{~cm} \\ \mathrm{Ab} 2 & 33-53 \mathrm{~cm} \\ & \\ \mathrm{Cb} 2 & 53-87 \mathrm{~cm} \\ \mathrm{Ab} 3 & 87-123 \mathrm{~cm}\end{array}$

Bwb3 $\quad 123-173 \mathrm{~cm}$

C1b3 173-218 cm

C2b3 218-278 cm

Ab4 $\quad 278-313 \mathrm{~cm}$
Unit III; brown (10YR 5/3) loamy sand; massive; hard; abrupt dipping. very dark grayish brown (10YR 3/2) fine sandy loam (leaf litter); moderate fine subangular blocky; slightly hard; abrupt dipping.

brown (10YR 4/3) fine sandy loam; massive; hard; clear dipping.

very dark grayish brown (10YR 3/2) clay loam; $20 \%$ brown (10YR 5/3); moderate medium subangular blocky; hard; clear dipping.

brown (10YR 4/3) silt loam; massive; slightly hard; abrupt smooth.

Unit II; very dark grayish brown (10YR 3/2) silt loam; moderate coarse subangular blocky; slightly hard; gradual smooth.

brown (10YR 4/3,5/3) loam; weak coarse subangular blocky; friable; gradual smooth.

brown (10YR 5/3) loam; faint horizontal laminations; friable; clear smooth. brown (10YR 5/3) silty clay loam; massive; slightly hard; abrupt smooth, lithic flake and mussel shell at $230 \mathrm{~cm}$.

very dark grayish brown (10YR 3/2) silty clay loam; weak coarse subangular blocky; hard.

\section{Profile 4: modern floodplain inset to Unit I; $340 \mathrm{ft}$ elevation; plastic wrapping at $150 \mathrm{~cm}$; calcareous throughout.}

C1 $\quad 0-47 \mathrm{~cm}$

C2 $\quad 47-152 \mathrm{~cm}$

C3 $\quad 152-320 \mathrm{~cm}$
Unit III; dipping laminations of light olive brown (2.5Y 5/3) fine sandy loam and black (10YR 2/1) clay loam; 5\% yellowish red (5YR 4/6) iron stains along laminations; abrupt dipping.

horizontal beds of brown (10YR 5/3) fine sandy loam and very dark gray (10YR 3/1) clay; 5\% yellowish red (5YR 4/6) iron stains along laminations; abrupt smooth.

beds of dark grayish brown (10YR 4/2) clay and yellowish brown (10YR 5/4) fine sandy loam; $2 \%$ yellowish red (5YR 4/6) iron stains along laminations. $420 \mathrm{~cm}$ water level of Picosa Creek. 